\title{
2001-2009 elevation and mass losses in the Larsen A and B embayments, Antarctic Peninsula
}

\author{
Christopher A. SHUMAN, ${ }^{1}$ Etienne BERTHIER, ${ }^{2}$ Ted A. SCAMBOS ${ }^{3}$ \\ ${ }^{1}$ UMBC-GEST, NASA Goddard Space Flight Center, Greenbelt, Code 698, Maryland 20771, USA \\ E-mail: christopher.a.shuman@nasa.gov \\ ${ }^{2}$ Centre National de la Recherche Scientifique, Université de Toulouse, Legos, 14 av. Edouard Belin, \\ Toulouse Cedex 31400, France \\ ${ }^{3}$ National Snow and Ice Data Center, 1540 30th Street, CIRES, Campus Box 449, University of Colorado,
} Boulder, Colorado 80309-0449, USA

\begin{abstract}
We investigate the elevation and mass-balance response of tributary glaciers following the loss of the Larsen A and B ice shelves, Antarctic Peninsula (in 1995 and 2002 respectively). Our study uses MODIS imagery to track ice extent, and ASTER and SPOT5 digital elevation models (DEMs) plus ATM and ICESat laser altimetry to track elevation changes, spanning the period 2001-09. The measured Larsen B tributary glaciers (Hektoria, Green, Evans, Punchbowl, Jorum and Crane) lost up to $160 \mathrm{~m}$ in elevation during 2001-06, and thinning continued into 2009. Elevation changes were small for the more southerly Flask and Leppard Glaciers, which are still constrained by a Larsen B ice shelf remnant. In the northern embayment, continued thinning of $>3 \mathrm{~m} \mathrm{a}^{-1}$ on Drygalski Glacier, 14 years after the Larsen A ice shelf disintegrated, suggests that mass losses for the exposed Larsen B tributaries will continue for years into the future. Grounded ice volume losses exceed $13 \mathrm{~km}^{3}$ for Crane Glacier and $30 \mathrm{~km}^{3}$ for the Hektoria-Green-Evans glaciers. The combined mean loss rate for 2001-06 is at least $11.2 \mathrm{Gta}^{-1}$. Our values differ significantly from published mass-budget-based estimates for these embayments, but are a reasonable fraction of GRACE-derived rates for the region $\left(\sim 40 \mathrm{Gta}^{-1}\right)$.
\end{abstract}

\section{INTRODUCTION}

Since Vaughan and Doake's (1996) broad analysis of early changes to Antarctic Peninsula ice shelves, numerous studies have shown that ice shelves are responding dramatically to regional climate change with substantial area losses (Cook and Vaughan, 2010), and changes in their tributary glaciers have also been observed (De Angelis and Skvarca, 2003; Rack and Rott, 2004; Rignot and others, 2004; Scambos and others, 2004; Cook and others, 2005; Marshall and others, 2006; Hulbe and others, 2008; Pritchard and others, 2009). Following the collapse of the Larsen A ice shelf in January 1995 (Rott and others, 1996), interferometric synthetic aperture radar (InSAR) data revealed that two tributary glacier systems increased flow speed (Rott and others, 2002). Following the Larsen B ice shelf break-up in early 2002 (Scambos and others, 2003), up to eightfold velocity increases for Hektoria, Green, Evans, Crane and Jorum glaciers were observed (Rignot and others, 2004; Scambos and others, 2004). Using a combination of ice velocity from InSAR, modeled surface accumulation, a digital elevation model (DEM) and mass conservation principles, Rignot and others (2004) also estimated thinning of tens of $\mathrm{m} \mathrm{a}^{-1}$ over portions of these glaciers. Scambos and others (2004) used initial data from NASA's Ice, Cloud and land Elevation Satellite (ICESat) acquired in 2003 to estimate elevation losses of up to $38 \mathrm{~m}$ in $\sim 6$ months during 2003 on lower Hektoria Glacier. In contrast to these changes, Flask and Leppard Glaciers, which flow into the southern remnant of the Larsen B ice shelf (SCAR Inlet ice shelf) and are therefore still buttressed by a substantial amount of floating ice, show only slight deceleration or no significant change (Rignot and others, 2004; Scambos and others, 2004). Unbuttressed smaller glaciers south of Crane Glacier also show little change (Hulbe and others, 2008). Preliminary bathymetry data for the now-exposed ocean areas in front of these small glaciers (e.g. Mapple, Melville and Pequod glaciers) show that they have relatively shallow fjords. Therefore, they are likely to be further from flotation at their ice fronts, more restrained by basal shear and less influenced by ice-shelf back-stress. In a continent-wide study, Pritchard and others (2009) used ICESat repeat track data from 2003 to 2007 and reported significant elevation decreases (up to $10 \mathrm{~m} \mathrm{a}^{-1}$ ) for many glacier basins in the Antarctic Peninsula, but did not assess individual glacier losses there in detail (their fig. 2 and supplementary fig. 10). Their analysis documents continued losses during 2003-07 for tributary glaciers that once flowed into the Larsen A and other collapsed ice shelves in the Antarctic Peninsula. For some glaciers, this is decades after ice-shelf disintegration.

Recent mass-budget studies for the Larsen $\mathrm{A} / \mathrm{B}$ area (e.g. Rignot and others, 2004, 2008; Rignot, 2006; Rott and others, 2011) report mass losses between $\sim 4$ and $\sim 31 \mathrm{Gt} \mathrm{a}^{-1}$ respectively, for portions of our study area and overlapping time periods. Results from the Gravity Recovery and Climate Experiment (GRACE) satellite system are more consistent at 38-43 Gt a ${ }^{-1}$ (Chen and others, 2009; Luthcke and others, 2009; Ivins and others, 2011), but these studies integrate over the entire northern portion of the Antarctic Peninsula, including Graham Land. Despite some variations in magnitudes, numerous studies have shown that the major glaciers draining into these two collapsed ice-shelf areas have been accelerating and lowering substantially, contributing mass to the global ocean, whereas small glaciers and those still buttressed by an ice shelf have changed much less.

The overall cause for these observed glacier and ice-shelf changes is thought to be increasing air temperatures; this has been observed at weather stations on both sides of the Antarctic Peninsula over the past several decades (Skvarca 
and others, 1999; Vaughan and others, 2001; King and Comiso, 2003; Vaughan and others, 2003). As initially suggested by Robin and Adie (1964), ice shelves in the region have decreased in area by many thousands of $\mathrm{km}^{2}$ over the same period (Cook and Vaughan, 2010). As suggested by Mercer (1978), two mechanisms likely explain these observed ice-shelf changes: (1) air-temperature increases in the 1990s have led to longer melt seasons and an increase in the extent of melt ponds on the northernmost ice shelves (Scambos and others, 2000; Fahnestock and others, 2002); and (2) over the same period, ocean circulation changes in the Weddell Sea may have caused enhanced basal melting of the Larsen Ice Shelf and thereby contributed to collapse (Shepherd and others, 2003; Vieli and others, 2007; Glasser and Scambos, 2008). In accordance with predictions, recent studies by Van den Broeke (2005) and Marshall and others (2006) showed that the major 2002 Larsen B ice shelf collapse was preceded by record high air temperatures, reduced sea-ice cover, and ultimately variations in the Southern Hemisphere Annular Mode that are attributed to anthropogenic climate forcing. Observed progressive northsouth ice-edge retreats and glacier velocity increases suggest that continued warming trends threaten remaining Antarctic Peninsula ice-shelf/glacier systems (e.g. Cook and others, 2005; Pritchard and Vaughan, 2007). As discussed by Hughes (1975) and Mercer (1978) and more recently by Hulbe and others (2008), understanding this effect and the response of individual drainage basins is critical to predicting ice-sheet mass-balance and sea-level changes under projected future warming conditions.

Clearly, there is an extensive published record on the break-up and subsequent observed changes within the drainage basins of the Larsen A and B and other nearby ice shelves. By combining satellite imagery with multiple laser altimetry datasets, our study can more fully assess the rapidly changing tributary glaciers of the Larsen A (Drygalski Glacier) and Larsen B (Hektoria, Green, Evans, Jorum and Crane glaciers) embayments for the period 2001-09. The goal of our study is to accurately quantify multi-year changes in ice extent and ice elevation, and to derive changes in ice mass across these glaciers. This quantification of the elevation and mass losses, as well as the timing of these changes, are essential for improved flow models for this part of Antarctica and predictions of future sea-level rise.

\section{DATA AND DATA MANAGEMENT}

We used NASA's Moderate Resolution Imaging Spectroradiometer (MODIS) imagery to track ice extent, and the Japan/NASA Advanced Spaceborne Thermal Emission and Reflection Radiometer (ASTER) and Centre National d'Êtudes Spatiales (CNES)/Satellite Pour I'Observation de la Terre (SPOT) Image Corporation's SPOT5 DEMs plus NASA's Airborne Topographic Mapper (ATM) and ICESat laser altimetry to track elevation changes during 2001-09. To assess mass losses contributing to sea level from the study area, we used MODIS Mosaic of Antarctica (MOA) grounding line positions derived from visible imagery collected between November 2003 and February 2004 (Scambos and others, 2007; referred to as MOA-2004 in this paper) as well as an earlier grounding line position derived from InSAR data acquired in the late 1990s (Rack and Rott, 2004; referred to as R\&R-1999 in this paper). To provide context for our discussions of ice extent and elevation change, we use Vaughan and Doake's (1996) nomenclature for the subdivision of the 'Larsen Ice Shelf' into A, B, C and $\mathrm{D}$ components (north to south respectively). We refer here to the small southern remnant of the Larsen B ice shelf as the SCAR Inlet ice shelf. In addition, the remaining ice-shelf area between the Larsen A and Larsen B embayments is referred to as the Seal Nunataks ice shelf (Ferrigno and others, 2006, 2008). The study area and key geographic features are shown in Figure 1.

\subsection{MODIS images}

Imagery from MODIS available at the US National Snow and Ice Data Center (NSIDC) was used to map changes in ice extent. Thirty MODIS images spanning October 2001 to November 2009 were contrast-enhanced, cropped and then layered into a georeferenced image stack along with other graphical information. By examining these images sequentially we were able to draw the boundary between sea ice or open water and the margins of glacier or ice-shelf areas. MODIS Channel 2 (the sensor band used in the images) has a $250 \mathrm{~m}$ resolution at nadir when directly above its target and can reveal many terrain details, but clouds obscured the ice fronts in some cases (Fig. 1). Accuracy of the boundary position, including errors due to image co-registration, differences in solar illumination angle and sensor viewing angle, and ice-edge mismapping, is better than $1 \mathrm{~km}$. Iceedge changes at the seasonal to annual scale were generally much larger than this, as seen in Figure 1.

\subsection{Satellite image photogrammetric DEMs}

Three ASTER (2001-04) and two SPOT5 (2006) satellite stereo imagery DEMs provide the large-scale context for the laser altimetry data. The availability of a pre-collapse (2001) DEM for the Larsen B tributary glaciers was crucial for this study's elevation-change goals. As of late 2009, there were no later high-quality imagery-based DEM data across the study area. Areas of unreliable elevations may occur in the DEMs due to clouds or correlation artifacts in featureless areas (Berthier and Toutin, 2008). Clouds have been delimited manually in the images, and corresponding areas of the DEM were masked. Most correlation artifacts for the SPOT5 DEMs can be discarded using the correlation mask provided with the elevation dataset (Korona and others, 2009). No correlation mask is provided with the ASTER DEM obtained using the SILCAST software (Fujisada and others, 2005). Instead, we used the correlation mask derived from the same ASTER stereo pairs using another software program (PCl Geomatica 10.1).

For our reference DEM, the November 2006 SPOT5 DEM, we estimated biases using ICESat data acquired during campaign Laser 3G, from 25 days before to the same day as the acquisition date of the SPOT5 stereo pair (Table 1). After converting the DEM elevations to the same TOPEX/Poseidon ellipsoid used by ICESat, we extracted the corresponding SPOT5 DEM elevation for each ICESat footprint using bilinear interpolation. A vertical bias of $3 \mathrm{~m}$ (std dev. $5.5 \mathrm{~m}, \mathrm{~N}=558$ ) was derived and corrected. All other DEMs were vertically adjusted to this November 2006 SPOT5 DEM. Although our differential DEM analyses are restricted to regions where both the earlier and later DEM elevations are reliable, individual pixel errors in the DEM can exceed tens of meters. However, averaging over large regions reduces the uncertainties significantly (Berthier and others, 2004, 2010). We estimated errors for the elevation 
Table 1. ICESat repeat profile dates for tracks used in this study

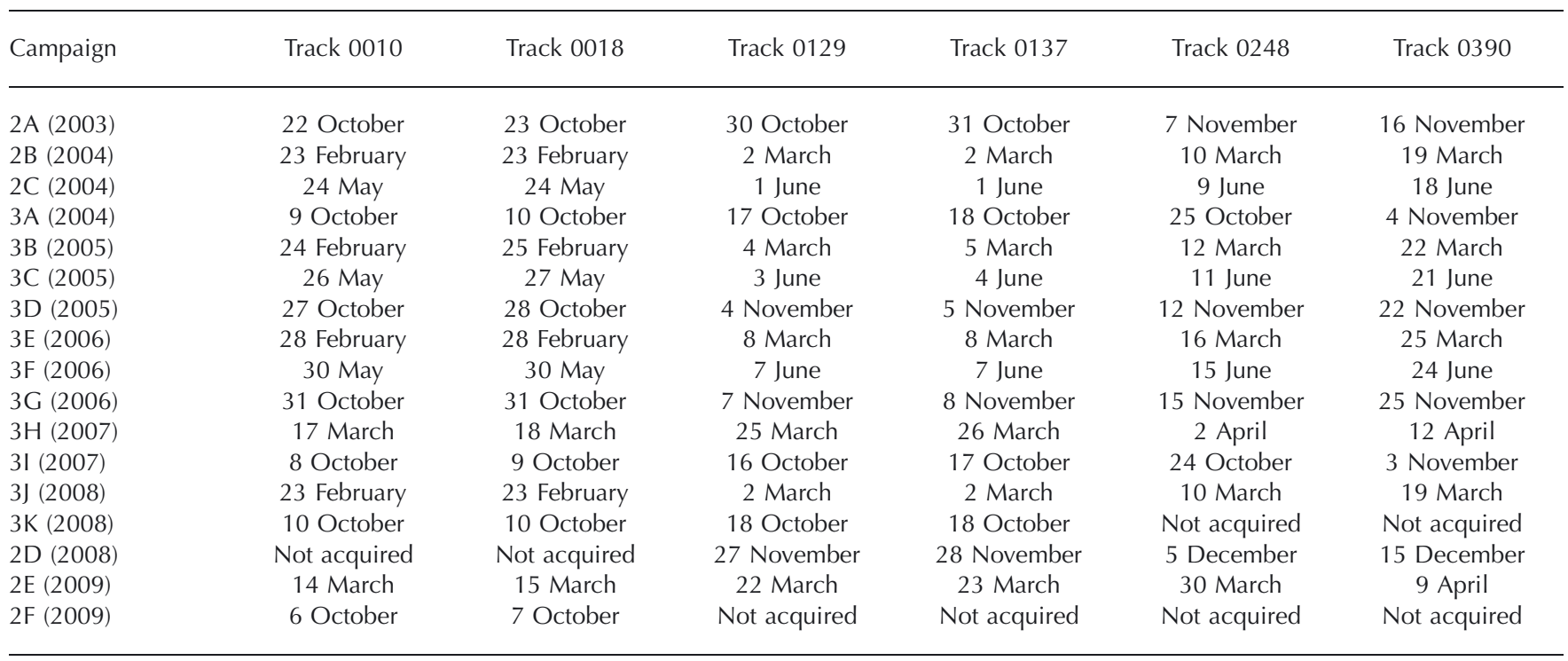

differences by examining average elevation differences on nunataks; we obtained a maximum error of $5 \mathrm{~m}$, which is an upper bound estimate of error given that slopes are likely to be higher on nunataks and DEM errors are known to increase with slope (Toutin, 2002). Following manual editing to remove outliers, the general accuracy of the DEMs is confirmed by their local agreement with more precise ICESat and ATM elevation profiles acquired at nearly the same time (e.g. Figs 3 and 4; Scambos and others, 2011).

\subsection{Satellite and airborne laser altimetry}

We used two different types of laser altimetry: airborne laser altimetry from ATM and satellite laser altimetry from ICESat. Figure 1 illustrates the coverage of these altimetry datasets during each year of the study period. To enable accurate comparisons of ATM with the ICESat data, we converted them to the TOPEX/Poseidon ellipsoid and then removed the EGM2008 geoid. Prior to NASA's IceBridge program, ATM profiles were available in late 2002, 2004 and 2008; this study is confined to the data acquired prior to the end of the ICESat mission in 2009. Additional elevation data from satellite imagery and IceBridge will be used in a future study (http://nsidc.org/data/icebridge/index.html).

As a result of the ATM instrument's design and for flight safety reasons, most data during these flights were acquired along curved glacier valleys due to their lower topographic slopes, or over relatively smooth inland ice areas (Krabill and others, 2002). In general, these flights occurred during good visibility periods, so there were few data problems due to clouds. In comparison, ICESat's repeat satellite altimetry coverage was generally more frequent in a given year but spatially limited to repeats along specific ground tracks and temporally limited due to its orbit and the timing of ICESat data campaigns. As satellite ground tracks were often cloudcovered at the observation time (Schutz and others, 2005), significant gaps in the profiles occurred (Fig. 1). Figure 2 shows the repeatability of ATM and ICESat profiles in more detail. The relatively wide spacing between ATM repeat tracks in the west Crane tributary acquired in 2004 and 2008 was due to aircraft control issues. ICESat tracks could also be widely spaced, with repeat passes being offset by up to $300 \mathrm{~m}$ across track (similar values are reported by Fricker and others (2007) and Brunt and others (2010)). Figure 2 illustrates the actual footprint locations of the ICESat data across the study area and provides an example of repeat track precision during the mission. ICESat's across-track spacing can complicate elevation change detection in dynamic glacier systems via repeat-track analysis, since the non-exact repeats sample different regions of the underlying topography (Smith and others, 2009; Abdalati and others, 2010).

\subsubsection{Airborne laser altimetry}

Details of the ATM instrument, its nominal decimeter-level accuracy and other characteristics, including a discussion of data quality and processing, are given by Krabill and others (2002). The laser is a pulse system operating at 3000$4000 \mathrm{~Hz}$, with a nutating mirror that makes helical scans over the underlying topography. Discussions of the initial flights over the study area on a Chilean Navy P-3A aircraft and comparisons of ATM and early ICESat data respectively are contained in Thomas and others (2004, 2005). ATM's acquired swath data are reprocessed by an evolving program, initially called ICESS (now ICESSN; neither is an acronym) that fits a number of $\sim 70 \mathrm{~m}$ diameter planes to the laser spot data on both sides of the aircraft. The along-track distance between center points of the planes is the distance that the aircraft moves in $0.5 \mathrm{~s}$. With a nutation rate of $4 \mathrm{~Hz}$, there is a $\sim 50 \%$ overlap between consecutive planes. For this study, we used ATM ICESS data from flights on 26 November and 10 December 2002 and 29 November 2004. The estimated vertical accuracy for the 2002 ATM data is $\sim 0.4 \mathrm{~m}$ (Thomas and others, 2004). Additional ATM data from 21 and 26 October 2008 flights were acquired by a new ATM data system and were reprocessed from the raw swath measurements using an enhanced algorithm, ICESSN. Under optimum circumstances, this produces multiple profiles of overlapping planes across the swath width, plus a 'nadir' profile as opposed to the pair of profiles generated by the ICESS processing. However, the new data system also produces periodic 1s gaps in the 2008 and subsequent altimetry profiles (Fig. 2). 


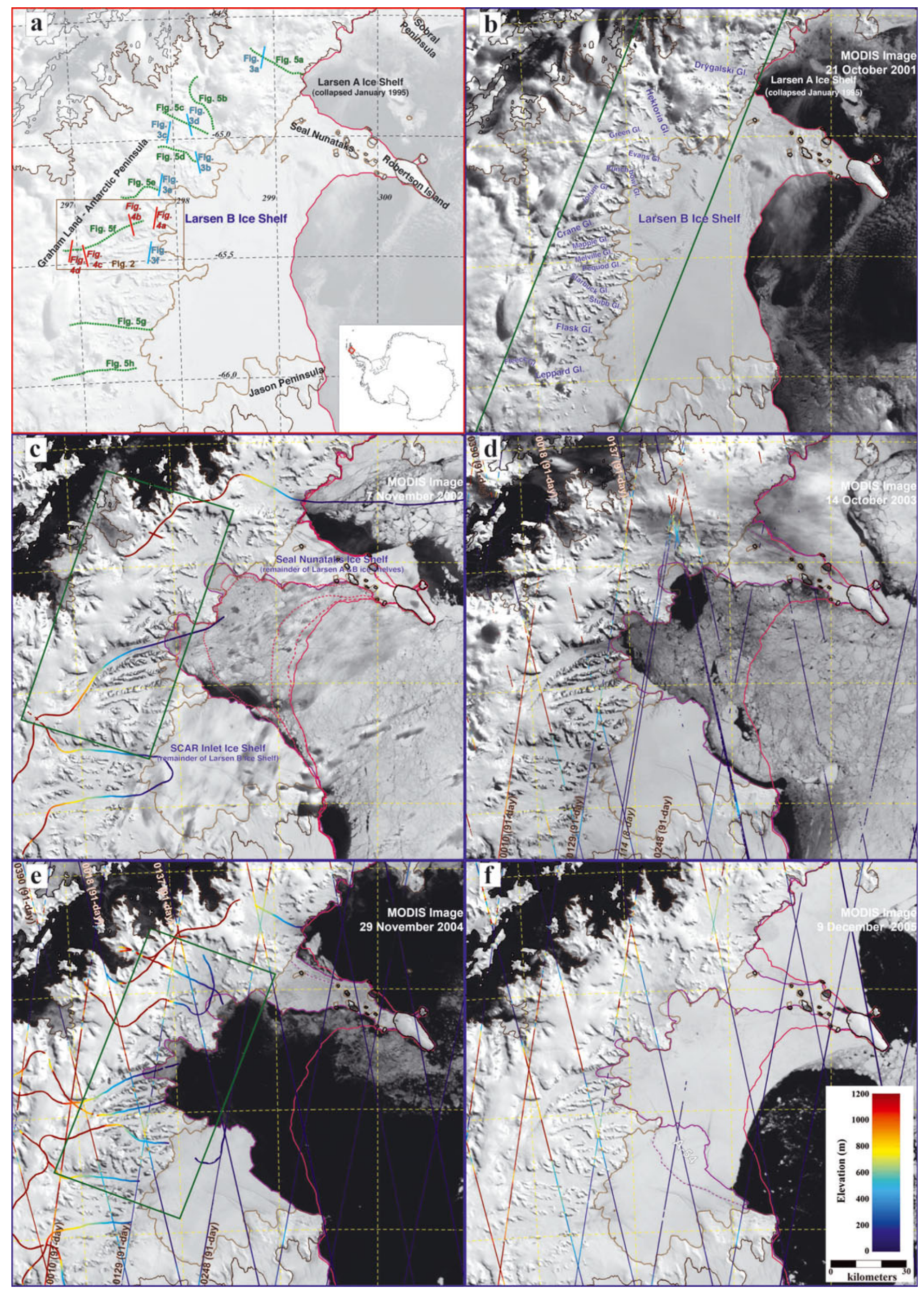

Fig. 1. Caption on opposite page. 


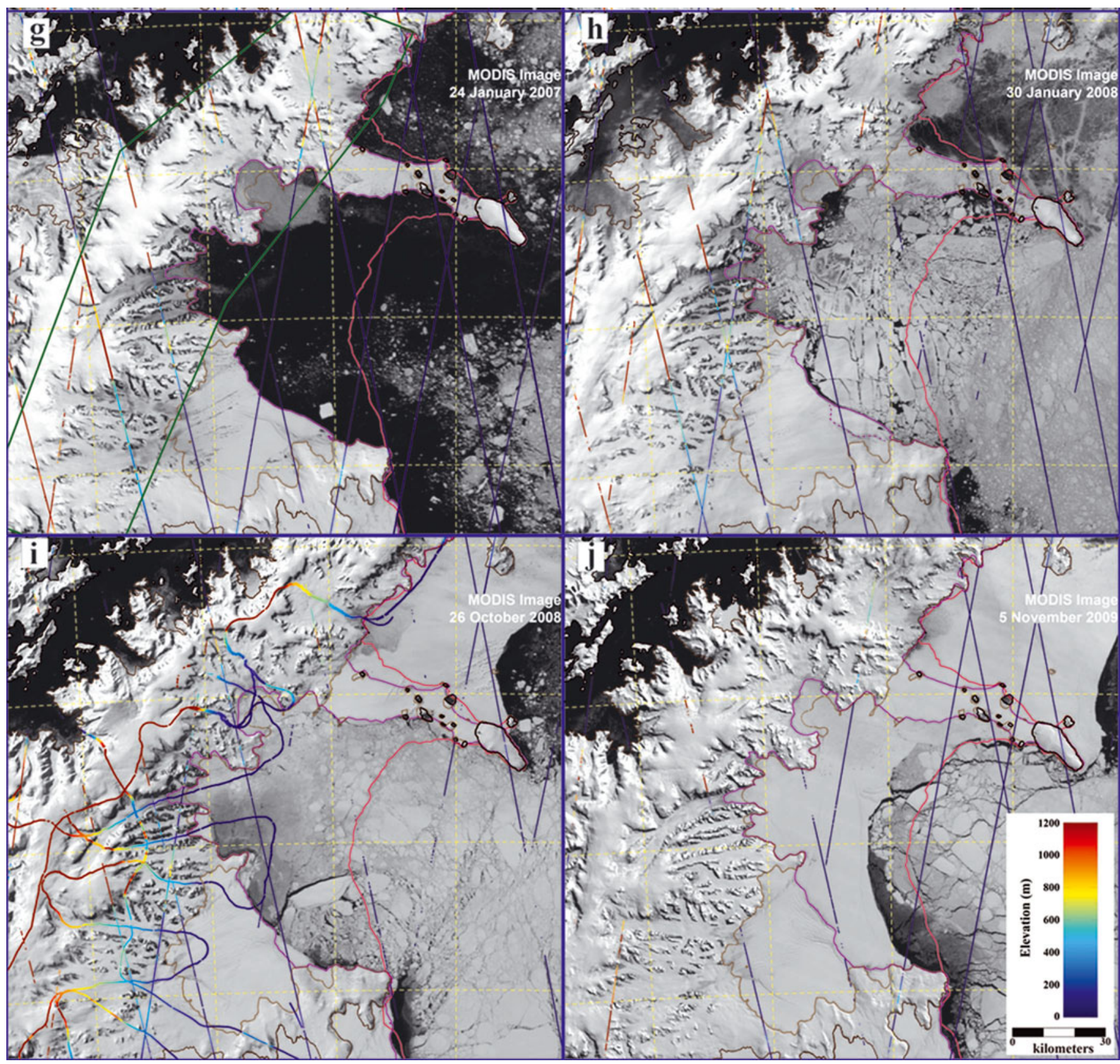

Fig. 1. Annotated MODIS images of the study area (approximately annually from 2001 to 2009) showing the positions of some subsequent figures, names and positions of selected landscape features and locations of the different altimetry datasets. The 2001 ice edge (solid magenta curve), the R\&R-1999 grounding line (light brown curve) and the position of the coast and grounding lines from MOA-2004 (grey curves) are shown in each panel. A solid purple curve shows the position of the ice edge in the austral summer for each year, and dashed purple lines indicate larger nascent icebergs. The elevation color scale for all altimetry data is shown in (f) and (j). ICESat tracks are labeled with their track number. (a) shows the area covered by Figure 2, positions of the data plotted in Figures 3-5, and names of selected geographic features. (b) labels all glaciers discussed in the text; green lines indicate the coverage of the 22 November 2001 ASTER DEM. (c) illustrates the Larsen B ice shelf's break-up in early 2002 (dashed magenta lines: retreating east-to-west ice-edge positions on 31 January, 23 February, 5 March and 17 March 2002). The resulting SCAR Inlet and Seal Nunataks ice shelf remnants defined during 2002 are also labeled. Color-coded curves show the ATM altimetry data acquired in 2002. The green rectangle shows the coverage of the 7 November 2002 ASTER DEM. (d) shows ICESat Laser 1 AB and 2A (2003) altimetry data by color-coded straight lines. (e) shows ICESat Laser 2B, 2C and 3A (2004) data by color-coded straight lines and ATM data acquired in 2004 as color-coded curves. The green rectangle indicates the coverage of the 27 September 2004 ASTER DEM. (f) shows ICESat Laser 3B, 3C and 3D (2005) data by color-coded straight lines. Also shown is $\sim 600 \mathrm{~km}^{2}$ iceberg A-54. (g) shows ICESat Laser 3E, 3F and 3G (2006) data by color-coded straight lines. The two angled green lines indicate the 25 November 2006 SPOT5 DEM. (h) shows ICESat Laser $3 \mathrm{H}$ and 3I (2007) data by color-coded straight lines. (i) shows ICESat Laser 3J, 3K and 2D (2008) data by color-coded straight lines and ATM data acquired in 2008 as color-coded curves. (j) shows ICESat Laser $2 \mathrm{E}$ and $2 \mathrm{~F}$ (2009) data by color-coded straight lines. See Table 1 for dates of all possible ICESat 91 day repeat tracks.

\subsubsection{Satellite laser altimetry}

ICESat was launched in January 2003 and acquired altimetry data first in an 8 day repeat orbit using Laser 1 during February-March 2003, again from September into early
October 2003 using Laser 2 and then switched to a 91 day repeat orbit in October 2003. From September 2003, ICESat's altimeter was operated in campaign mode, where data were only acquired for $\sim 33$ days two or three times a 


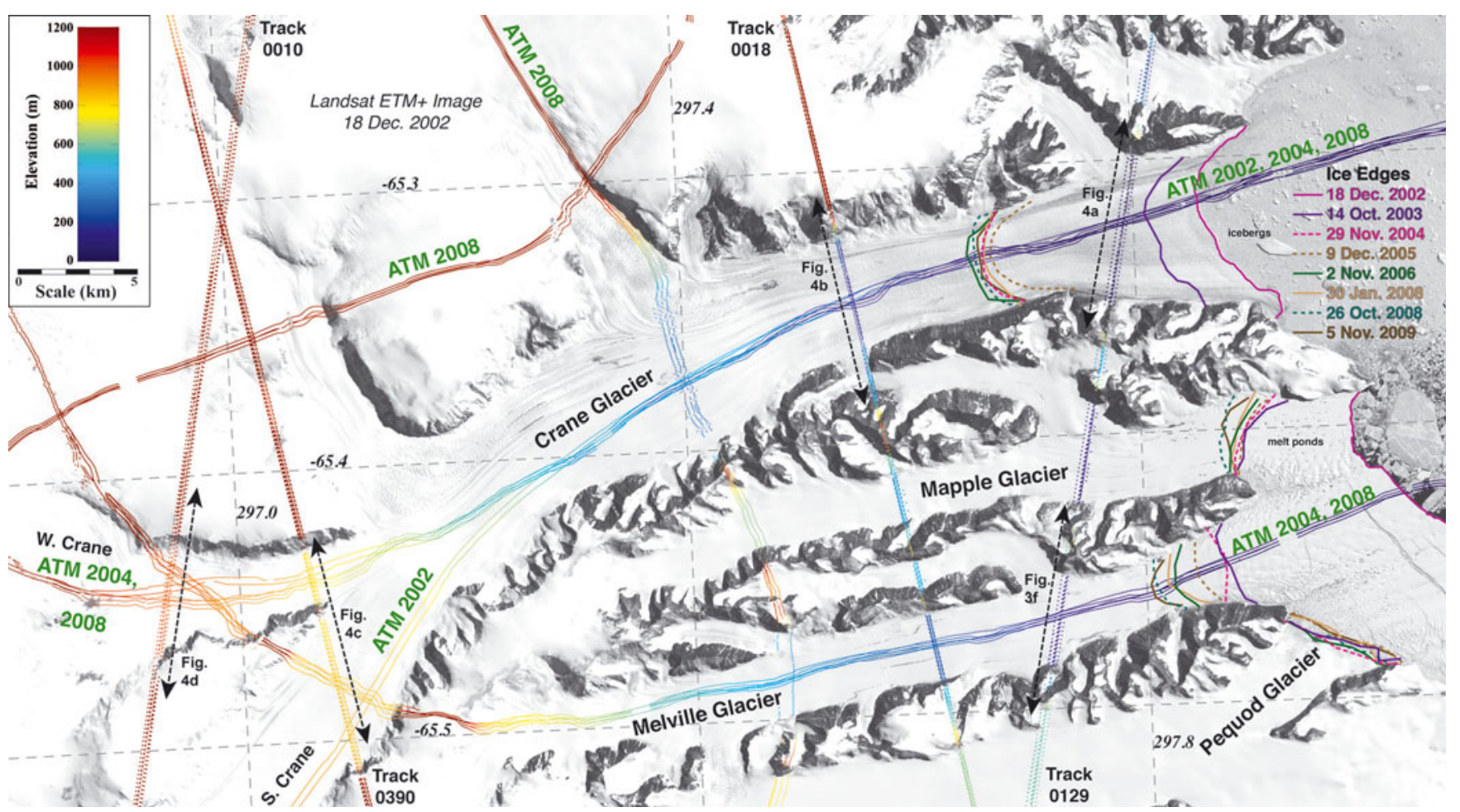

Fig. 2. The Crane Glacier region (Fig. 1a for location) showing all laser altimetry data and ice-edge positions on a Landsat Enhanced Thematic Mapper Plus (ETM+) image acquired on 18 December 2002. Curves indicate the ATM data locations, and straight lines show the individual altimetry footprints for the available ICESat repeat tracks. All altimetry data are color-coded using the elevation scale at upper left. The locations of one cross section in Figure 3 (lower Melville Glacier) and all cross sections in Figure 4 (Crane Glacier) are also indicated.

year (Schutz and others, 2005). Besides the track 114 data from 2003 discussed by Scambos and others (2004), we used six repeat elevation profiles from the partial 91 day ICESat track pattern during 2003-09 (Fig. 1d-j). These profiles measured Drygalski, Hektoria, Green, Evans, Jorum, Crane, Melville, Flask and Leppard glaciers as well as additional terrain in the study area from 22 October 2003 to 7 October 2009 (Table 1). We used Release 531 elevation data from ICESat's GLA06 product (available from NSIDC), which consists of a series of varying elliptical footprints with a general diameter of $\sim 70 \mathrm{~m}$ every $\sim 172 \mathrm{~m}$ along track. To avoid ambiguity, we use three-digit track numbers for 8 day tracks (up to track 119) and four-digit numbers for 91 day tracks (up to track 1354) (Fig. 1d). See information at NSIDC for more on ICESat campaigns (e.g. http://nsidc.org/data/ icesat/laser_op_periods.html).

Under clear-sky conditions and on low slopes, ICESat measurements were generally accurate to $\pm 14 \mathrm{~cm}$ (Shuman and others, 2006). Clouds affected ICESat in several ways throughout the mission. In the worst cases, cloud cover can completely obscure the laser pulse's ground return, resulting in extensive or local elevation-data loss in profiles over the study area (gaps in Fig. 1 and also Figs 3 and 4). In some cases, the laser energy is reflected from cloud tops, resulting in elevation values that were significantly too high. To remove these spurious elevations, we progressively deleted points whose values were $>130 \mathrm{~m}$ greater than the mean of all repeats at that location, recalculating the mean until none exceeded the threshold. Thinner cloud and/or blowing snow conditions can affect laser pulse transmission through the atmosphere less substantially, leading to range delay and a negative elevation bias of up to a few meters (Smith and others, 2005). Due to higher than expected received laser energy pulses, ICESat detectors were frequently saturated during the laser campaigns with the highest transmit energies. This degraded the waveforms used to assess pulse timing and also leads to a negative elevation bias. We corrected all affected ICESat data using the standard saturation correction value in the Release 531 data product (Sun and others, 2004).

\section{RESULTS AND DISCUSSION}

Over the study period, there were substantial changes to the combined glacier termini and remaining ice-shelf area edge positions (Figs 1 and 2). From the progressive edge positions, we calculate net area changes to compare with other studies (e.g. Cook and Vaughan, 2010). Utilizing the three different types of altimetry data (DEMs, ATM and ICESat), we evaluated elevation changes at selected glacier cross sections, calculated elevation-change rates along centerline glacier profiles and then assessed volume loss regionally. Each of these results is discussed individually in the following subsections and then summarized.

\subsection{MODIS ice-edge changes}

After mapping the combined glacier termini and remaining ice-shelf area edge positions using MODIS imagery (Fig. 1), we calculated net area changes to compare with other studies (e.g. Scambos and others, 2003; Cook and Vaughan, 2010). The major collapse event of Larsen B ice shelf, documented in numerous publications and totaling $\sim 3250 \mathrm{~km}^{2}$ between late January 2002 and early March 2002 (Scambos and others, 2003), was the most rapid and significant edge retreat in the area during the study interval (Fig. 1c). Large losses continued after March 2002 across the remaining ice-shelf areas as well as at glacier termini, 
totaling $\sim 1865 \mathrm{~km}^{2}$ by late 2009 . This total includes the $\sim 600 \mathrm{~km}^{2}$ iceberg A-54 that calved in early 2006 (Fig. 1f), as well as other icebergs that broke free from the SCAR Inlet and Seal Nunataks ice shelf areas. An additional $342 \mathrm{~km}^{2}$ was lost from the Larsen A ice shelf's margins between late 2001 and late 2009, primarily from along the northern margin of the Seal Nunataks ice shelf (e.g. Fig. 1j). These area changes are similar to those reported by Cook and Vaughan (2010).

Glacier front retreats of $>5 \mathrm{~km}$ occurred on Crane, Jorum and Hektoria-Green-Evans glaciers. The Hektoria-GreenEvans glacier system was especially dynamic, with the edge advancing and retreating multiple times since early 2002. A substantial embayment began to form there in late 2002 and was named 'Vaughan Inlet' in 2008. This inlet expanded in 2007-09, effectively separating the three glaciers (cf. Fig. 1f and g; Rott and others, 2011). Further south, Crane Glacier's ice front position retreated rapidly through 2002 until late 2004 (Fig. 2), and a substantial amount of $>1 \mathrm{~km}$ thick (Mueller and others, 2006) partially grounded ice calved away to form the Crane fjord (see further discussion below). Some retreat also occurred on the smaller Melville Glacier and to a lesser extent in front of Mapple and Pequod Glaciers (Fig. 2).

\subsection{Glacier cross-section elevations}

We selected ten elevation cross sections (Figs 3 and 4, located on Fig. 1a) to assess the timing and pace of surface lowering across the region. ICESat tracks were not always perpendicular to flow and some were oblique to flow. We selected the locations to maximize temporal knowledge of the variation in elevation over the study period. We present and discuss results by region in the following subsections.

\subsubsection{Drygalski Glacier}

The elevation changes from November 2001 to early 2009 along ICESat track 0248 across upper Drygalski Glacier are shown in Figure 3a; this track crosses the glacier obliquely, $15-20 \mathrm{~km}$ upstream of the MOA-2004 grounding line (Fig. 1a and b). Elevation losses were fairly steady over the study period and were uniform along the track; the maximum elevation loss over the period at this location is $>30 \mathrm{~m}$. We note that the Drygalski's ice-edge position (from our MODIS analysis) and the extent of intense crevassing (as seen in high-resolution optical imagery, not shown here) remained nearly unchanged through the study period, 6-14 years after the loss of the Larsen A ice shelf. Rott and others (2011) report that the velocity of Drygalski Glacier has remained stable since 1999 .

\subsubsection{Evans Glacier}

The magnitude and timing of elevation loss across Evans Glacier is shown in Figure $3 \mathrm{~b}$. This location was $5 \mathrm{~km}$ upstream of the R\&R-1999 grounding line (Fig. 1a and b; Rott and others, 2011, fig. 2) and is almost perpendicular to flow. The elevation time series (Fig. 3b) shows a major early change across the entire profile (up to $50 \mathrm{~m}$ decrease between late 2001 and early 2004). This is followed by a bifurcation across the glacier, with less change at midprofile, a steady elevation decrease on the main trunk to the north, and the formation of a distinct convex-upward surface on both the southern and northern branches. This suggests that Evans Glacier began to float at this location in 2007, which we discuss in more detail below. Net elevation changes of nearly $-100 \mathrm{~m}$ occurred on the southern part of
Evans Glacier, with slightly smaller losses on the northern main glacier trunk. Inspection of MODIS imagery shows that the intersection point of the ATM flight-line with ICESat track 0137 occurs close to where the two glacier branches merge. There is less elevation lowering, $\sim 10 \mathrm{~m}$ lowering, between the offset 2004 and 2008 ATM datasets at this location than elsewhere on lower Evans Glacier (cf. the temporally equivalent Laser $3 \mathrm{~A}$ and $2 \mathrm{D}$ profiles in Fig. 3b). This suggests that ATM data were acquired over a medial moraine between the two branches of the glacier (Rott and others, 2011, fig. 2).

\subsubsection{Green Glacier}

Green Glacier was covered by two ICESat tracks: track 0129 crossed obliquely over the central part of Green Glacier, $\sim 20 \mathrm{~km}$ upstream of the late 1990s grounding line; track 0137 crossed lower Green Glacier and was nearly perpendicular to ice flow (Fig. 1a and b). Elevation changes from 2001 to 2008 along these tracks are shown in Figure 3c and $d$ respectively. At the up-glacier location, thinning did not clearly begin until late 2006, nearly 4 years after loss of the Larsen B ice shelf. After a period of relative stability during 2003-05, there was a major ice-front retreat (tidewater glacier calving) that began during 2006 (Fig. 1f and g). By late 2008, total elevation changes exceeded $-30 \mathrm{~m}$ (Fig. 3c), but there were no ATM data available at this location to compare with the track 0129 data to help further resolve the timing of surface lowering. Elevation losses on lower Green Glacier (track 0137) began soon after the collapse of the Larsen B ice shelf (similar to Evans Glacier), and continued progressively until the end of these data in 2008. Elevation loss was fairly consistent through time across this section (unlike the losses of similar net magnitude across Evans Glacier's two channels) and totaled $\sim 100 \mathrm{~m}$ over the study period. ATM data in 2004 and 2008 were consistent with the nearly contemporaneous ICESat profiles (ICESat campaigns Laser 3A and 2D). The extracted DEM elevations capture the overall topography at this location and were generally consistent with the laser altimetry data, but are less precise than the other elevation data over this cross section.

\subsubsection{Jorum Glacier}

ICESat track 0129 crossed lower Jorum Glacier nearly perpendicularly to ice flow $\sim 5 \mathrm{~km}$ above the R\&R-1999 grounding line, as well as an adjacent small tributary obliquely to flow (Figs $1 \mathrm{a}$ and $\mathrm{b}$ and 3e). Jorum Glacier was not suitable for ATM data collection due to its overall topography. Elevation losses on the main Jorum Glacier trunk appear to have started almost immediately after the initial Larsen B ice shelf collapse, even though the ice shelf at this location persisted through late 2003 (Fig. 1). The elevation change was $\sim-30 \mathrm{~m}$ between late 2001 and late 2003; then the thinning rate slowed during 2004. Seasonal calving of the remaining ice shelf past the $R \& R-1999$ grounding line occurred in 2004, and between late 2004 and late 2006 there was a return to a thinning rate of $\sim 15 \mathrm{~m} \mathrm{a}^{-1}$. The total elevation change approached $-60 \mathrm{~m}$ by late 2008 . The shape of the cross-glacier profile also changed, with greater thinning along the margins of Jorum Glacier. This topographic form was similar to that of lower Evans Glacier (by 2007) and is discussed further below. Along the Jorum's small northern tributary (left side of Fig. 3e), crossed farther inland from the R\&R-1999 grounding line and obliquely by the 

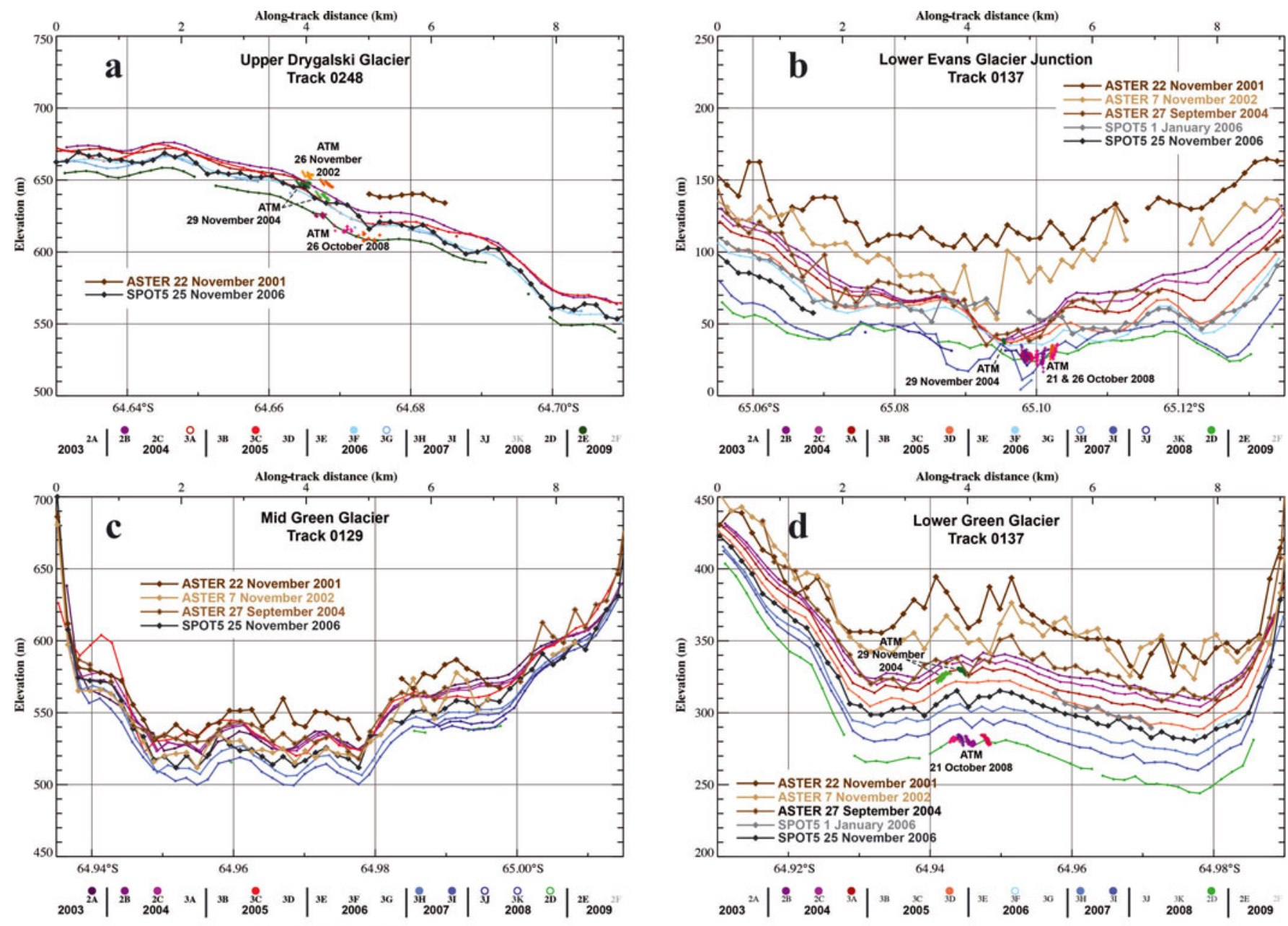

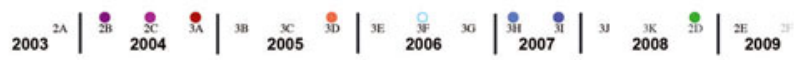
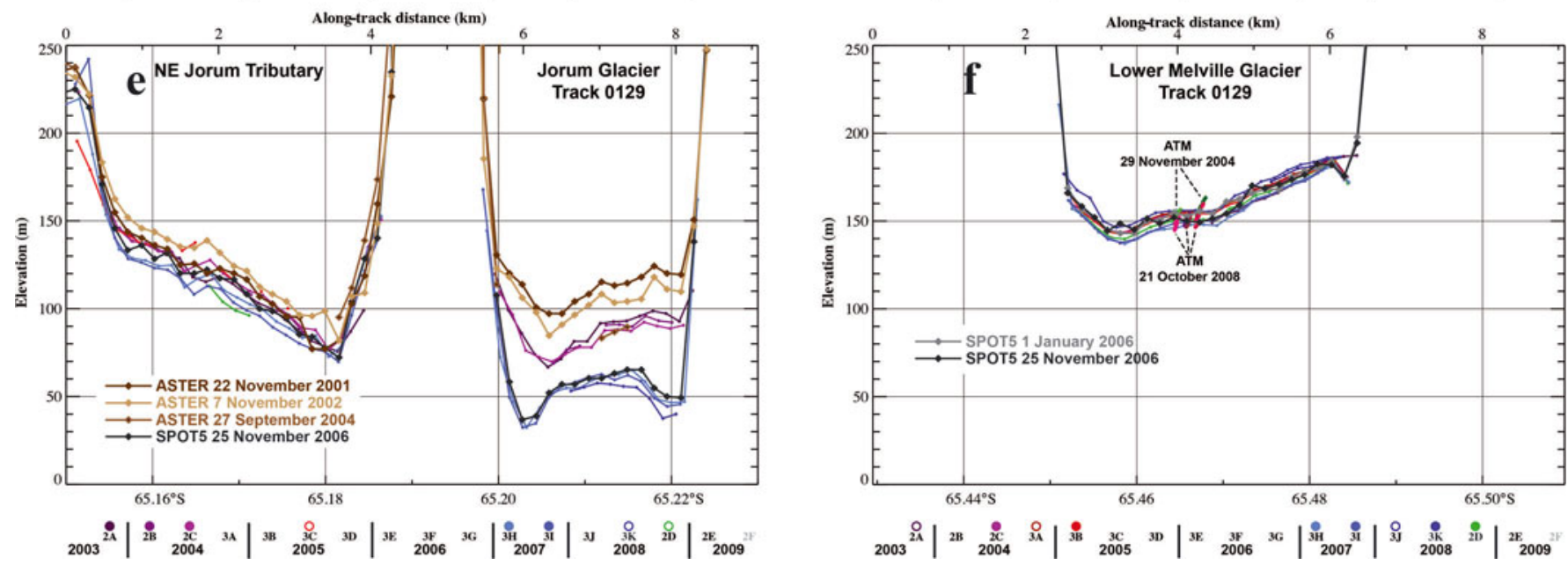

Fig. 3. Elevations for glacier cross sections (Fig. 1a for locations) using all available altimetry datasets (2001-09). Profiles are oriented with north to the left and are similarly scaled with a vertical exaggeration of $\sim 25 \times$. The ASTER and SPOT5 DEM data are shown as colored diamonds. Colored crosses indicate ATM data points within $100 \mathrm{~m}$ of ICESat shot locations; no ATM data are available for (c) and (e). Colored dots indicate ICESat repeat-track elevations. For each track, the relative timing and availability of elevation data for each ICESat campaign are shown by the unique scale below each plot (circles are filled if the profile was extensive; unfilled if only limited data were available; absent if no data were retrieved; and have grey labels if ICESat was not in altimetry acquisition mode) (Table 1 for the dates of all possible 91 day repeat tracks).

ICESat track, the elevation change was smaller, $-20 \mathrm{~m}$ overall, and relatively steady through the study period.

\subsubsection{Melville Glacier}

ICESat track 0129 obliquely crosses lower Melville Glacier $\sim 5 \mathrm{~km}$ upstream of the R\&R-1999 grounding line (Figs 1a and b, 2 and $3 f)$. There are fewer elevation data available on this glacier because the earliest stereo imagery did not resolve elevations for this glacier, and the first ATM profile was not acquired until late 2004 (Fig. 2). The ICESat data show that little elevation change occurred over 2003-08. We estimated a maximum elevation change of $\sim-5 \mathrm{~m}$ by comparing the 2004 and 2008 ATM profiles. Analysis of the MODIS imagery shows that the ice edge in front of Melville 

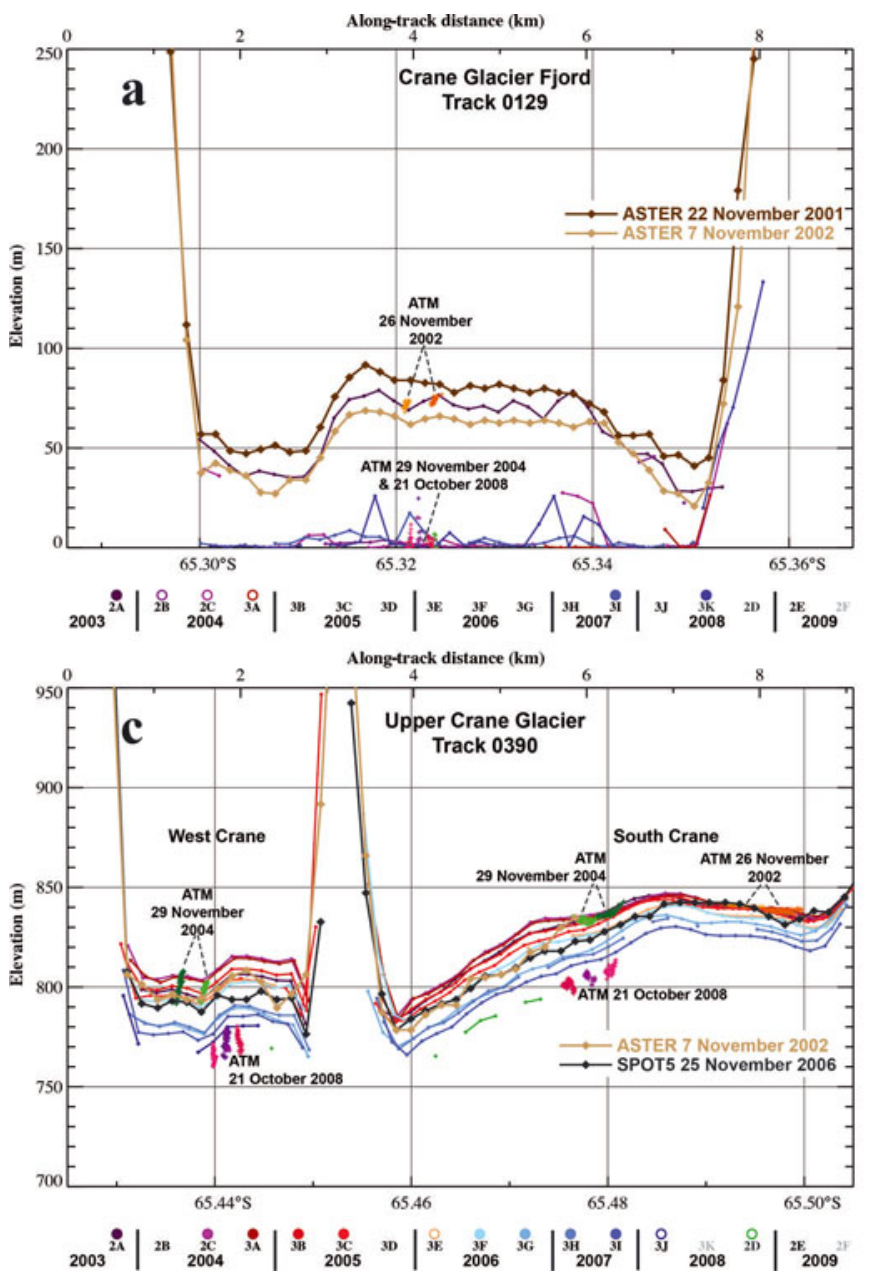
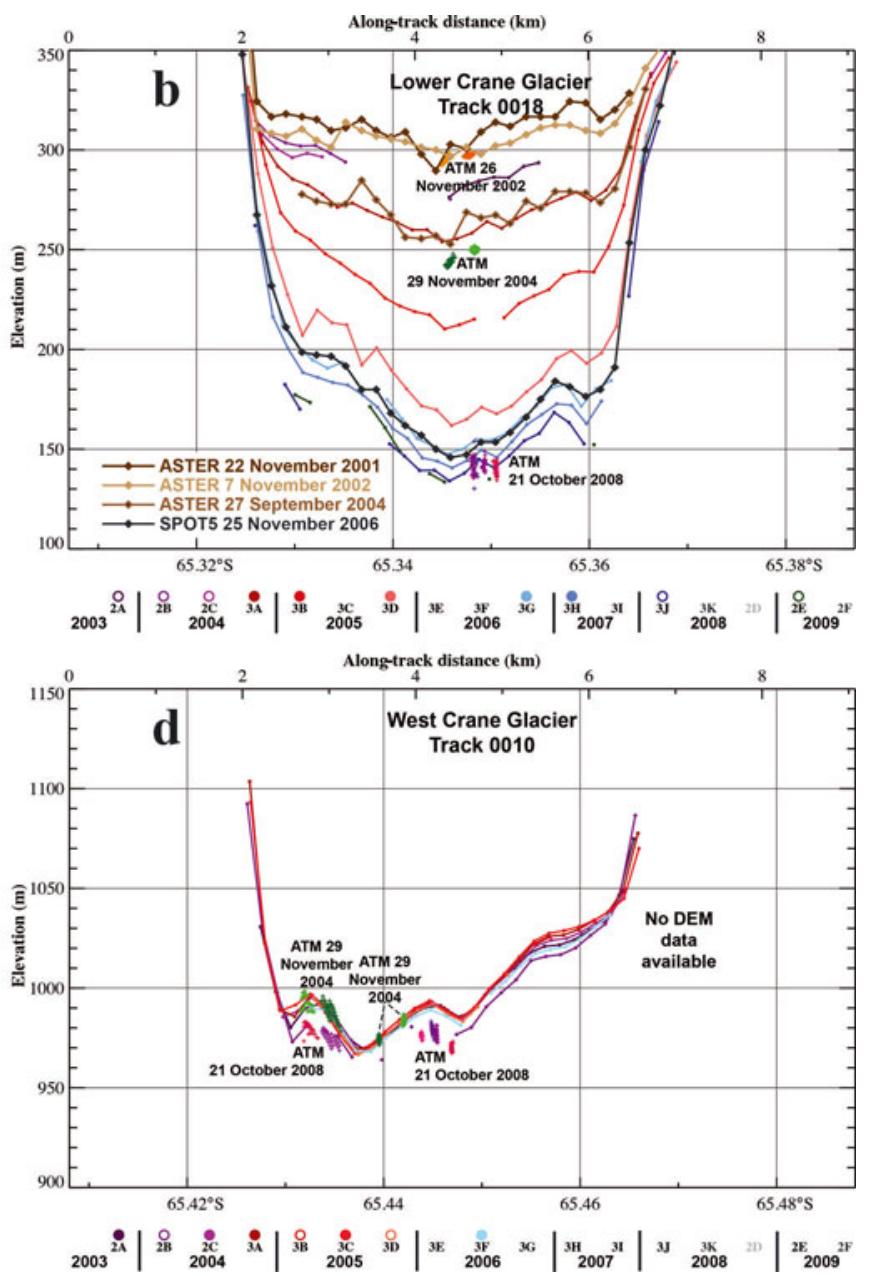

Fig. 4. Elevations for Crane Glacier cross sections (locations shown in Figs 1a and 2) using all available altimetry datasets (2001-09). Notation and symbols are as described in the Figure 3 caption.

Glacier did not retreat as far or as rapidly as it did for the larger glaciers to the north in the Larsen B embayment (Figs 1 and 2). These results suggest that Melville Glacier and adjacent small glaciers, such as the Pequod and Mapple (also crossed by ICESat track 0129; Fig. 2), are not responding as much as adjacent and larger glaciers such as Crane Glacier even though they are all now similarly exposed to the ocean. The along-flow slope of Melville Glacier from ATM elevation data (shown only in map view in Fig. 2) indicates it is generally steeper near the grounding line than nearby larger glaciers like Flask Glacier, suggesting that basal shear is greater for the smaller and narrower glacier. We discuss the limited responses of the Melville and similar glaciers below.

\subsubsection{Crane Glacier}

Crane Glacier is the longest glacier system $(>50 \mathrm{~km})$ in the study area and has extensive ICESat, ATM and DEM data coverage (Figs 1 and 2). There were four ICESat tracks across the glacier, varying from nearly perpendicular to fairly oblique to ice flow; these 'cross-section' locations enabled a detailed assessment of elevation change progressively along the glacier over the study period (Fig. 4).

ICESat track 0129 crossed the former lower Crane Glacier just upstream of the R\&R-1999 grounding line (Fig. 1a and b), and was slightly oblique to flow (Figs 2 and 4a). The initial elevation data from the 2001 DEM showed a strongly convex-up profile, with an ice elevation of close to $80 \mathrm{~m}$ in the center of the glacier prior to ice-shelf disintegration, and margins that are as much as $30 \mathrm{~m}$ lower. This form, similar to the topographic shape subsequently measured on the lower Evans and Jorum glaciers, is discussed further below. The late 2002 DEM revealed a $\sim 15 \mathrm{~m}$ decrease in central elevation but a similar profile shape. Elevations were relatively constant between the 26 November 2002 ATM data and the first ICESat (Laser 2A) profile on 23 October 2003 and showed that the central portion of the glacier was $\sim 5 \mathrm{~m}$ higher than the 2002 DEM. The Crane Glacier terminus disintegrated just after this (Scambos and others, 2011, fig. 4) but we cannot resolve the causes of the apparent elevation variation. Icebergs in the fjord were occasionally profiled by later ICESat passes (e.g. Laser 2C and $3 \mathrm{~K}$ data in Fig. $4 \mathrm{a}$ ).

ICESat track 0018 crossed nearly perpendicularly over what is now lower Crane Glacier, $\sim 13 \mathrm{~km}$ upstream of the R\&R-1999 grounding line (Figs $1 \mathrm{a}$ and $\mathrm{b}$ and 2). Along this track, a very large elevation change on the order of $-170 \mathrm{~m}$ occurred during 2001-09 (Fig. 4b). The elevations shown in Figure $4 \mathrm{~b}$ also indicate the value of integrating multiple datasets, as this enabled better resolution of the timing and pace of the elevation losses. We note that $90 \mathrm{~m}$ of the overall thinning occurred between late 2004 and late 2005. Timing of this increased pulse of surface lowering, both here and up-glacier, appears to be connected to further retreat of the Crane Glacier ice front in late 2004 to near its current position (Fig. 2). A companion study (Scambos and others, 
2011) attributes part of the anomalous elevation change to drainage of a subglacial lake that was triggered by the front retreat and steepening of the glacier. Mueller and others (2006) and E. Domack (personal communication, 2011) show that the late 2004 ice-front position coincided with a bathymetric high, and the glacier front now rests in a deeper portion of the submarine trough and is partially floating. The trough was mapped in detail in 2006 by multi-beam sonar after the fjord was exposed. The ice-front position has varied over time within a narrow range since early 2006 (Fig. 2).

We note that the thinning was not uniform across the glacier and was most pronounced close to the northern limit of the 2002 ATM data. Also note the consistency of the 2006 DEM profile in magnitude and topographic form with the contemporaneous ICESat Laser 3G elevation data (Fig. 4b). Since 2006, with a stable ice-front location $\sim 5 \mathrm{~km}$ downstream of track 0018, thinning of the lower trunk decreased to perhaps $5 \mathrm{~m} \mathrm{a}^{-1}$, and apparently reduced even more since the Laser 3J pass in early 2008 into early 2009 (a few shots from the track 0018 Laser 2E campaign were acquired here in early 2009; Fig. 1j). The increased elevation variation in the 2008 ATM glacier center-line data does not indicate local slope here but rather the degree of crevassing where track 0018 crosses lower Crane Glacier as detailed by Scambos and others (2011).

ICESat track 0390 crossed the narrower and steeper west Crane Glacier nearly perpendicularly as well as the wider south Crane Glacier at $\sim 45^{\circ}$ (Figs $1 \mathrm{a}$ and $\mathrm{b}$ and 2). These tributaries join just to the east of this cross section to form the trunk of Crane Glacier at a position $\sim 40 \mathrm{~km}$ upstream of the pre-collapse grounding line (Figs $1 \mathrm{a}$ and $\mathrm{b}$ and $4 \mathrm{c}$ ). Elevations decreased from $\sim 2005$ to 2008 along this track, with a distinct acceleration in the rate of elevation loss beginning in late 2006 for both tributaries. The maximum elevation decrease exceeded $30 \mathrm{~m}$ where track 0390 obliquely crossed the south Crane Glacier channel and $40 \mathrm{~m}$ where it crossed the west Crane Glacier channel. The steep slope of the west Crane Glacier tributary, relative to the south channel, is indicated by the vertical spread of the spatially offset 2004 and 2008 ATM elevations as they intersect with the nearly perpendicular ICESat repeats (Figs 2 and 4c). As with Melville Glacier, plots of the ATM elevation data along flow are not presented here but are shown in map view in Figure 2. We note that the orientation of ICESat track 0390 across the south Crane Glacier tributary is more oblique to the ATM data compared with other locations, so more overlap of the two sets of altimetry data occurs here (Figs 2 and 4c).

ICESat track 0010 crossed west Crane Glacier slightly obliquely, $\sim 6 \mathrm{~km}$ further inland from track 0390 near the western limit of the glacier (Figs $1 \mathrm{a}$ and $\mathrm{b}$ and 2). Here elevation changes of $\sim-15 \mathrm{~m}$ are perceptible by comparing the 2008 ATM data with the 2006 (and earlier) elevation data on the northern part of the tributary (Fig. 4d). Highresolution imagery of this area reveals that the glacier is branching at this location, which explains the double hump shown in the elevation-data time series. We note that the partial ICESat track 0010 profile appears much lower than the other ICESat repeats; it is the furthest east of the ICESat repeats and may also have been affected by forward scattering. Further inland, south Crane Glacier was not well covered by ICESat, ATM and DEM data during the study period (e.g. Fig. 1e), which precludes a similar far-upstream assessment of this tributary, but we expect that thinning now extends to the limits of this tributary as well.
Taken collectively, the elevation data across Crane Glacier and the other Larsen B embayment glaciers to its north indicate that: (1) thinning had probably begun before our first elevation dataset was acquired (late 2001) and before the collapse of the Larsen B ice shelf, including a transition from grounded to floating state in at least lower Crane Glacier, and (2) at least two phases of elevation loss appear to progress up-glacier that seem to be associated with ongoing ice-shelf changes. In summary, the large Crane Glacier ( $\sim 50 \mathrm{~km}$ long) and several nearby glaciers had responded by 2008 to the break-up of the Larsen B ice shelf with substantial thinning across their basins.

\subsection{Evidence of grounding-line retreat and ice flotation in elevation data}

These glacier cross sections show that the topography of the lower Evans and Jorum glaciers evolved from broadly concave-up to convex-up during the study period (Fig. $3 \mathrm{~b}$ and e). In addition, the topography of lower Crane Glacier (Fig. 4a) was already distinctly convex-up at the beginning of the study period. As also discussed by Rott and others (2011), these topographic forms suggest that these glaciers have become ungrounded in deep fjords. An indication of the depths of the troughs for the various tributary glaciers comes from bathymetry information acquired offshore in the Larsen B embayment, in a series of cruises both before and after the main Larsen B ice shelf disintegration event in 2002 (Mueller and others, 2006; personal communication from E. Domack, 2011; see NBP0603 cruise at http://www. marine-geo.org/portals/antarctic/). Water depths up to $\sim 1100 \mathrm{~m}$ were measured by side-scan sonar within the broad U-shaped submarine trough offshore of the Crane fjord. A deep trough, up to $850 \mathrm{~m}$, was also measured offshore of Jorum Glacier. Ice conditions during the cruise prevented extensive acquisition of bathymetry data close to the termini of Evans, Green and Hektoria glaciers, but a trough of $>800 \mathrm{~m}$ was mapped a few kilometers from the mouth of their combined embayment (Fig. 1). In contrast, water depths near the glacial fronts of Melville and the adjacent smaller Pequod and Mapple glaciers indicate their troughs are much shallower (250 and $320 \mathrm{~m}$ respectively).

Elevations of lower Crane Glacier (Fig. 4a) in 2001 and 2002 were $\sim 80 \mathrm{~m}$ at the glacier center and were at least $30 \mathrm{~m}$ lower at the glacier's margins. From this topographic shape we propose that this section of Crane Glacier was likely already afloat in 2001, despite being upstream of the R\&R-1999 grounding line. Trough depth and flotation also explains the transition in the shape of lower Jorum Glacier (Fig. 3e), with the lower glacier taking on a similar topographic shape by late 2006 with a center elevation of $\sim 60 \mathrm{~m}$. Elevation data from the two tributaries of Evans Glacier close to the ice-edge position also suggest a topographic shape change occurred by 2007, with central elevations for each tributary of $\sim 50 \mathrm{~m}$ (Fig. 3b). Using specific ICESat profiles, Rott and others (2011) note flotation has occurred for Jorum and Evans Glaciers and include some estimates of inferred glacier thickness.

The convex-upward shape of these lower glacier trunks after flotation is consistent with the likely ice-thickness pattern for the glaciers. The thickest ice and deepest bed are found along the center line of the glacier, and the preflotation surface is relatively flat or concave-up in the crossglacier direction. As thinning proceeds, bringing a glacier to the point of flotation, the center of the glacier floats first. 
With continued uniform cross-glacier thinning, the thicker central section of the glacier tongue will rise higher than the margins, forming a convex topographic cross section. The central elevations of Jorum and Crane Glaciers are also consistent with flotation given the available bathymetric data. This assumes that thinning is driven largely by uniform longitudinal extension. Previous studies of the initial Crane Glacier ice acceleration have indicated that this is the case (Scambos and others, 2004; Hulbe and others, 2008). Once afloat, thinning of the total ice column will change surface elevation by only a fraction $(\sim 11 \%)$ of the net thinning as governed by the relationship between freeboard height and total glacier thickness. This fractional change after flotation is indicated by reduced elevation change rates near glacier fronts in the center-line profile elevation-change data discussed in section 3.4.

These elevation data suggest that Crane Glacier and its adjacent ice shelf were likely thinning at least between 1999 and 2001, possibly during the acquisition of InSAR data used for the R\&R-1999 grounding line. Additional convexup cross sections from the 2001 DEM data further inland along Crane Glacier (not shown here) also suggest that the grounding line position for this glacier (and possibly others in the study area) was substantially different by the time of the Larsen B ice shelf collapse in 2002.

\subsection{Glacier center-line elevation differences}

Since the ICESat tracks did not sample along the center lines of the glaciers in the study area, we extracted earlier and later DEM elevations along 2004 ATM profiles (Fig. 1e for ATM coverage). Center-line elevations for seven glaciers were extracted from the 2001 and 2006 DEMs, and the 2004 data were generally repeated by ATM in 2008. For Jorum Glacier, no ATM data were available, so elevation differences were generated from a center-line position on the 2001, 2004 and 2006 DEMs. We then differenced these datasets (late minus early) and divided by the elapsed time to derive a change rate as shown in Figure 5 and discussed in the remainder of the paper.

These data along eight glacier center lines show change rates over the length of each glacier incrementally during the majority of the study period. These elevation difference data, all beginning inland and ending at their seaward ice edges, show that several glaciers responded dramatically following the loss of Larsen B ice shelf (Fig. 5). Even those glaciers still protected behind the SCAR Inlet ice shelf (e.g. Flask and Leppard Glaciers) show some elevation differences over the study period, but it is not clear whether they are responding to broader ice-shelf changes or localized changes such as rifting (Fig. 1a and b for profiles and glacier locations). We discuss these results by region below.

\subsubsection{Larsen A embayment: Drygalski Glacier}

For Drygalski Glacier, surface lowering occurred along a substantial portion of the glacier length, and large decreases $\left(>10 \mathrm{~m} \mathrm{a}^{-1}\right)$ were observed between 2004 and 2001 in the lower portion of the basin (Fig. 5a). Due to cloud cover, the lower part of the glacier was not observed in the 2006 DEM, and some 2004 ATM data were also unavailable in the upper portion of the basin. Despite this, the 2006-2004 elevation difference rates show broad changes of $-5 \mathrm{ma}^{-1}$. These elevation losses appear to be slightly reduced at lower elevations in the 2008-2006 difference rate data (Fig. 5a). From the elevation data along the DEM and ATM profiles, we observed elevation-change rates comparable with the elevation changes $\left(-3 \mathrm{ma}^{-1}\right)$ observed along track 0248 across upper Drygalski Glacier (Fig. 3a).

\subsubsection{Larsen B embayment: glaciers with large elevation decreases}

The along-flow profiles for the Larsen B embayment glaciers (Hektoria, Green, Evans, Jorum and Crane) are broadly consistent. For each of them, the earliest elevation difference profile (2004-2001) shows a maximum surface lowering near the front of the glacier. Subsequent profile differences (2006-2004 and 2008-2006) show elevationchange maxima that are generally propagating upstream and broadening, suggesting that a kinematic wave of thickness, slope and speed changes was induced by the loss of the shelf in 2002. Furthermore, the reduced elevation loss rates observed near the seaward end of most of the profiles in Figure 5 is consistent with our inferred upstream grounding line movement and the resultant reduction in surface elevation change of floating glacial ice as discussed in section 3.3.

The profiles for Hektoria and Green Glaciers (Fig. 5b and c) are more similar to each other than the branching Evans Glacier (Fig. 5d). This may be due to the position of the ATM data relative to features on lower Evans Glacier (Fig. 3b and related discussion). In their lower reaches, Hektoria and Green Glaciers had $15-25 \mathrm{ma}^{-1}$ surface lowering rates during 2004-2001; similar or slightly lower rates during 2006-2004; and larger rates again during 2008-2006, with up to $30 \mathrm{~m} \mathrm{a}^{-1}$ thinning for Hektoria Glacier. The changes on Evans Glacier, except on the lower glacier where the losses were poorly resolved, were similar to the Green and Hektoria Glacier differences but had a reduced magnitude. Overall, these thinning-rate variations are likely associated with the continued retreat of the ice edge into this part of the Larsen B embayment since 2006 after a local readvance in 2004-05 (Fig. 1e-g).

Because no ATM data are available for Jorum Glacier (see above and Fig. 1), it was more difficult to assess the rate and timing of surface lowering on this glacier. Using DEM center-line data alone, we find that elevation changes occurred at a maximum rate of $-10 \mathrm{~m} \mathrm{a}^{-1}$ over 2004-2001 (Fig. 5e). Subsequently, as the ice edge moved farther inland, lower Jorum Glacier thinned more rapidly, up to $25 \mathrm{~m} \mathrm{a}^{-1}$ over 2006-2004. Given evidence of flotation since at least late 2006 from the available across-flow elevation data and small elevation changes since then (Fig. 3e), it is likely that the $-25 \mathrm{ma}^{-1}$ elevation change rate occurred on grounded ice inland; however, we lack detailed knowledge of the grounding line position for this glacier over time.

Elevation difference rates along Crane Glacier (Fig. 5f) were assessed from the west Crane tributary in the interior to the stable ice-front location it established beginning in early 2006 (Fig. 2). Early thinning rates (2004-2001) reached a maximum just behind this front at $25 \mathrm{ma}^{-1}$ and were not fully resolved inland due to the spatial limit of the 2001 DEM and a relatively featureless surface at that time. In the next interval (2006-2004), a sharp maximum in elevation change rate, close to $-60 \mathrm{~m} \mathrm{a}^{-1}$, was seen $\sim 6 \mathrm{~km}$ upstream from the 2006 ice front, and is related to the change of $-90 \mathrm{~m} \mathrm{a}^{-1}$ from late 2004 to late 2005 (Fig. 4b) This sharp localized decline is thought to be due in part to drainage of a small but deep subglacial lake (Scambos and others, 2011). Despite some small data gaps, the 2008-2006 data showed 

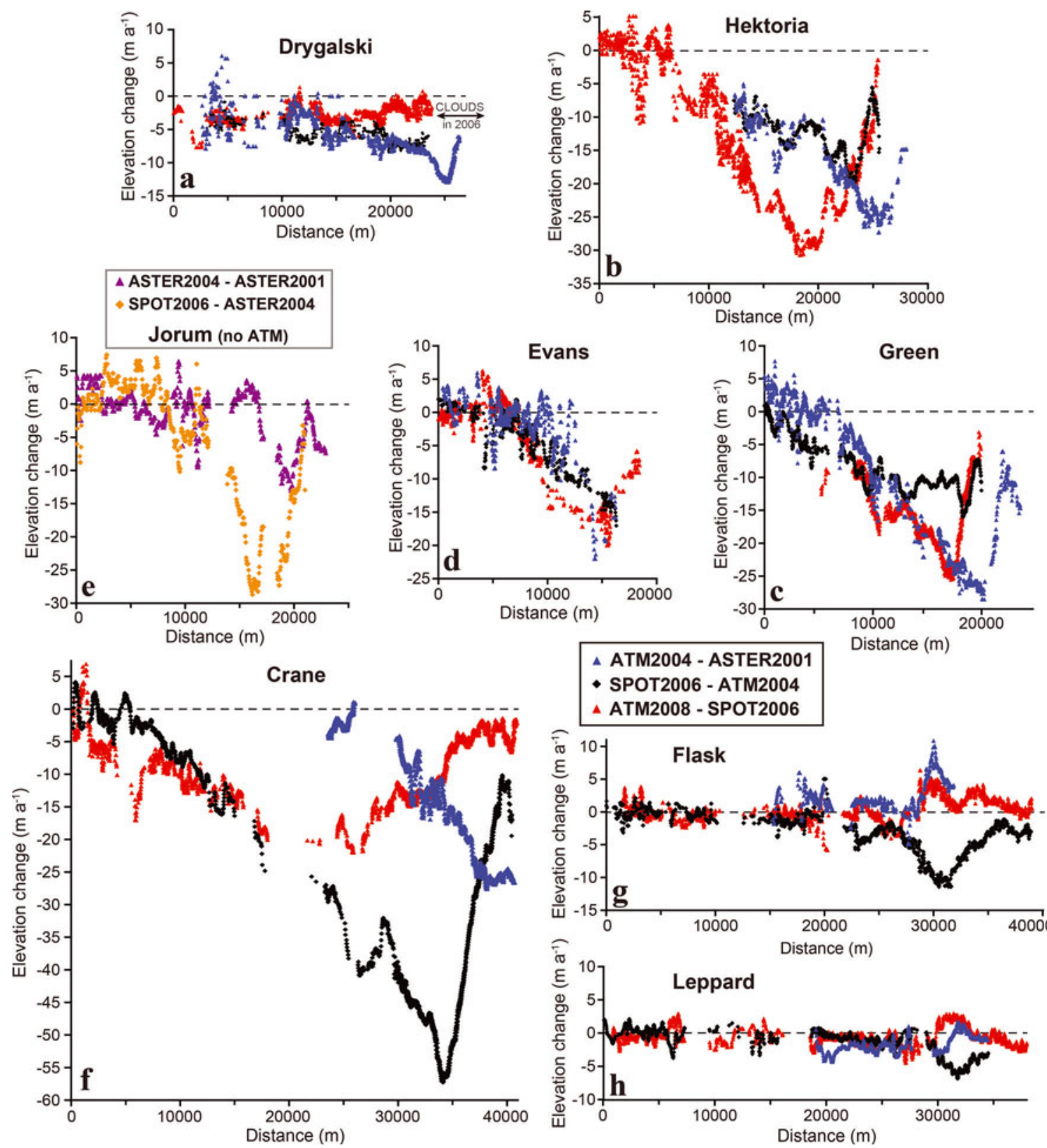

Fig. 5. Rate of elevation change along center-line profiles from interior to ice edge (Fig. 1a) for eight large glaciers in the study area. Axes are scaled the same for all panels. For all glaciers except Jorum (e; see separate key), center-line elevation change was measured by differencing ASTER DEM 22 November 2001 and ATM 29 November 2004 (blue triangles), ATM 29 November 2004 and SPOT5 DEM 25 November 2006 (black diamonds), and SPOT5 DEM 25 November 2006 and ATM 21 and 26 October 2008 (red triangles). Elevation differences for Jorum Glacier are measured by differencing ASTER DEM 22 November 2001 and ASTER DEM 27 October 2004 (purple triangles), and ASTER DEM 27 October 2004 and SPOT5 DEM 25 November 2006 (orange diamonds) data. ATM profiles are not exact repeats, but offsets are generally small (e.g. Fig. 2, west Crane Glacier). DEM imagery swath positions (shown in Fig. 1), cloud cover and/or quality issues for specific DEMs (e.g. Fig. 5a) limit the completeness of some of the elevation difference profiles.

an elevation thinning-rate maximum of $\sim 20 \mathrm{ma}^{-1}$ nearly $20 \mathrm{~km}$ inland. In this most recent elevation difference rate, the pattern of elevation change had clearly broadened, and progressed upstream. From the available data, we infer that a kinematic wave, indicated by the moving position of the maximum loss rate, progresses up-glacier at a rate of $>0.5 \mathrm{~km} \mathrm{month}^{-1}$. This kind of pattern (upsteam migration of the maximum thinning rate) is consistent with the pattern seen on the other glaciers, but is clearest for Crane.

Comparing the 2008 ATM with the 2006 DEM elevations, thinning rates exceed $10 \mathrm{ma}^{-1}$ well up into the west Crane tributary $\sim 35 \mathrm{~km}$ from the ice front. This is comparable with the track 0390 cross-section elevation data shown in
Figure 4c. Since the south Crane tributary was not profiled by ATM in 2004 or 2008, our results on the timing of Crane Glacier's surface lowering only apply to the smaller and shorter tributary (Fig. 2).

\subsubsection{Larsen B embayment: glaciers with small elevation changes}

Flask and Leppard Glaciers flow into the diminishing SCAR Inlet ice shelf. Net elevation changes were much smaller than for other substantial glaciers in the Larsen B embayment and do not show an upstream-migrating maximum thinning rate over the study period (Fig. $5 \mathrm{~g}$ and h). Instead, both glaciers show positive and negative surface elevation 

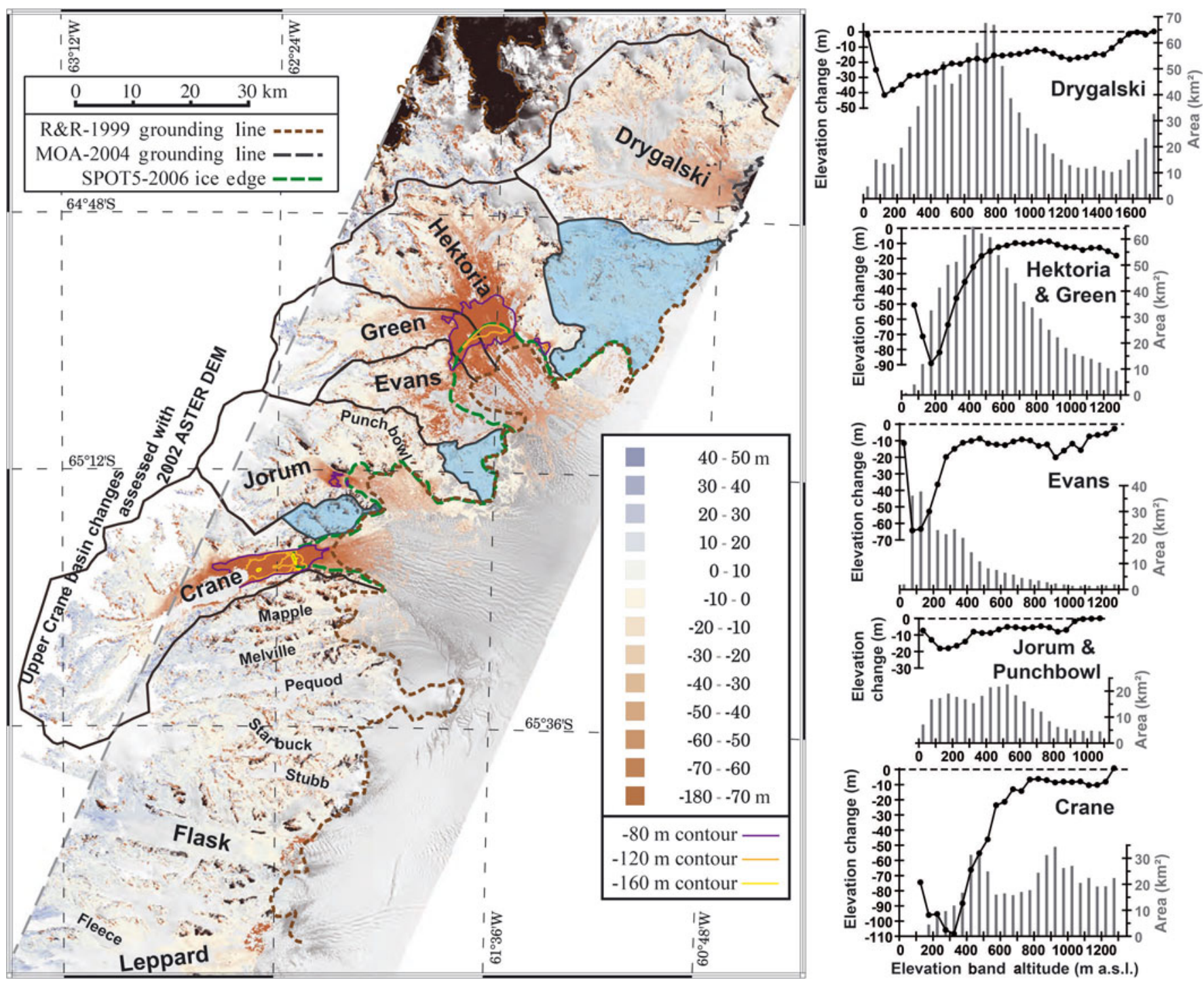

Fig. 6. Map of elevation differences between the 25 November 2006 (SPOT5) DEM and the combined 11 November 2001 and 7 November 2002 (ASTER) DEMs. Selected elevation-change contours (-80 purple, -120 orange and -160 yellow) depict the areas of the largest losses. The extents of the main drainage basins are outlined in black. The SPOT5-2006 ice edge and the combined MOA-2004 and R\&R-1999 grounding line positions are shown by dashed curves (SPOT5-2006 green, MOA-2004 grey and R\&R-1999 brown). Areas excluded from the Table 1 mass loss summary are either shaded blue or lie south of Crane Glacier's catchment. The area between the composite grounding line and the SPOT5-derived ice edge calved by 2006 and was evaluated separately in our mass-balance assessment because portions of the area may have been ungrounded by 2001 (Table 2, note*). Background is the 11 November 2001 pre-break-up ASTER image. Plots at right have consistent scale ranges and show the elevation changes from the DEM differencing averaged by $50 \mathrm{~m}$ altitude intervals across the grounded part of each glacier catchment (black dots). The hypsometry for each basin (grey histograms) is shown for the same elevation increments.

changes of roughly similar magnitude and timing. Examination of ATM and ICESat data near the grounding lines showed no tidal signal along the lower portion of the centerline profiles (Fig. 1). Therefore, we believe the elevationchange rates shown for Flask and Leppard Glaciers are from grounded ice. However, both glaciers showed a negative change rate $\left(-5\right.$ to $-10 \mathrm{~m} \mathrm{a}^{-1}$ for Leppard and Flask Glaciers respectively) during 2006-2004 just upstream of the R\&R1999 grounding line. We note that during this period the SCAR Inlet calved a $\sim 600 \mathrm{~km}^{2}$ iceberg (A-54; Fig. $1 \mathrm{f}$ and g; a MODIS image from 3 February 2006 shows the calving event). However, the same areas of these glaciers show positive (close to $+10 \mathrm{ma}^{-1}$ during 2004-2001 and $\sim+5 \mathrm{~m} \mathrm{a}^{-1}$ during 2008-2006 for Flask Glacier) to near-zero (close to $0 \mathrm{~m} \mathrm{a}^{-1}$ during 2004-2001 and $\sim+2 \mathrm{ma}^{-1}$ during 2008-2006 for Leppard Glacier) elevation-change rates before 2004 and after 2006. This suggests that the lower Flask and Leppard have had dynamic flow variations related to changes in the stress field, but the exact causes are unclear from the available data. From ice-penetrating radar profiles (not shown here; see https://www.cresis.ku.edu/ data/antarctic), we note that Flask and Leppard Glaciers appear to have deep troughs similar to Crane Glacier, so we predict that their response to a break-up of the remaining SCAR Inlet ice shelf will also be significant, but further study is clearly needed to understand their behavior.

Although they are no longer bounded by the Larsen B ice shelf, only small elevation changes have been detected during 2001-09 on the relatively narrow Melville (e.g. Fig. 3f), Pequod and Mapple glaciers (Fig. 6 and related discussion). These observations, together with the measurement of the relatively shallow submarine troughs in front of 
Table 2. Area, elevation and volume losses and estimated mass loss rates between 25 November 2006 and 22 November 2001 (except for the upper part of Crane Glacier where elevation changes are measured between 25 November 2006 and 7 November 2002)

\begin{tabular}{|c|c|c|c|c|c|c|c|c|}
\hline \multirow{3}{*}{ Glacier name(s) } & \multicolumn{4}{|c|}{ Ice that calved* } & \multicolumn{4}{|c|}{ Grounded ice: net change } \\
\hline & Area loss & $\begin{array}{c}\text { Mean } \\
\text { elevation loss }\end{array}$ & $\begin{array}{l}\text { Volume } \\
\text { loss }\end{array}$ & $\begin{array}{l}\text { Standard } \\
\text { error }\end{array}$ & Area & $\begin{array}{c}\text { Mean } \\
\text { elevation loss }\end{array}$ & $\begin{array}{l}\text { Volume } \\
\text { loss }\end{array}$ & $\begin{array}{c}\text { Standard } \\
\text { error }\end{array}$ \\
\hline & $\mathrm{km}^{2}$ & $\mathrm{~m}$ & $\mathrm{~km}^{3}$ & $\mathrm{~km}^{3}$ & $\mathrm{~km}^{2}$ & $\mathrm{~m}$ & $\mathrm{~km}^{3}$ & $\mathrm{~km}^{3}$ \\
\hline Drygalski & 0.0 & & & & 1015 & 15.2 & 15.4 & 5.1 \\
\hline Hektoria-Green & 72.8 & 79.9 & 5.8 & 0.4 & 752 & 28.9 & 21.7 & 3.8 \\
\hline Evans & 11.5 & 46.1 & 0.5 & 0.1 & 266 & 33.3 & 8.9 & 1.3 \\
\hline Jorum-Punchbowl & 25.1 & 39.8 & 1.0 & 0.1 & 351 & 9.0 & 3.2 & 1.8 \\
\hline Crane $^{\dagger}$ & 33.8 & 80.0 & 2.7 & 0.2 & 470 & 28.1 & 13.2 & 2.4 \\
\hline All glaciers ${ }^{\ddagger}$ & 143.2 & & 10.0 & 0.8 & 2854 & & 62.4 & 14.4 \\
\hline Rate of mass loss $\left(G t a^{-1}\right)^{\S}$ & & & $1.8^{\circ}$ & 0.1 & & & 11.2 & 2.6 \\
\hline
\end{tabular}

*'Ice that calved' area losses are derived by comparing the SPOT5-2006 ice edge with earlier grounding line information and may include some ungrounded ice by late 2001 .

Assumes elevations in the higher portion of the study area, covered by the November 2002 DEM, did not change between November 2001 and November 2002 and losses are averaged over 5 years.

\#All glaciers' does not include glaciers to the south of Crane Glacier or small unnamed drainage areas (see blue areas in Fig. 6). For these excluded glaciers, small (but not significant) elevation losses have been detected.

${ }^{\S}$ Assumes a bulk density for the ice volume lost of $900 \mathrm{~kg} \mathrm{~m}^{-3}$ (after Rignot and others, 2004, 2008; Rott and others, 2011).

"These volume and mass losses were derived from the freeboard volume and will be an overestimate where the ice-shelf surface was higher than the hydrostatic level due to partial grounding or marginal support.

them (section 3.3), suggest that either a near-flotation condition (parameter $h_{\mathrm{c}}^{\prime}$; see Vieli and others, 2001), or deep ocean circulation and melting (or both) would be required for large mass-balance changes for these glaciers.

\subsection{DEM differencing and mass loss}

We estimated the total volume loss across the region between 2006 and 2001 by differencing the SPOT5 25 November 2006 and the ASTER 22 November 2001 DEMs (Fig. 6). The 2001 ASTER DEM did not entirely cover the most inland part of the study area, primarily the upstream portion of Crane Glacier's basin. Therefore, we substituted the ASTER 7 November 2002 in place of the 22 November 2001 DEM in this region (Fig. 6 and the DEM's respective coverage areas in Fig. $1 \mathrm{~b}$ and $\mathrm{c}$ ). Merging the two ASTER DEMs is justified by the small elevation differences calculated for the inland portion of the overlap region (November 2002-November 2001 has a mean of $4.9 \mathrm{~m}$; also see accuracy discussion in section 2.2).

The accuracy of the DEMs is demonstrated by their local agreement with ICESat and ATM elevation profiles (section 2.2; examples in Figs 3 and 4). Our difference map covered only regions where DEM elevations were reliable (Fig. 6). We estimated glacier volume change for the areas with no reliable difference data by calculating the elevation change versus altitude for measured areas and applying the appropriate value to the entire glacier based on its hypsometry (Berthier and others, 2010). Summing the estimated DEM difference value for these regions with the measured changes for each altitude increment, we obtained a total volume change for each glacier (Fig. 6; Table 2).

To restrict our analysis to regions that were likely to be grounded prior to ice-shelf collapse in the Larsen B embayment and, thus, that directly contributed to sea-level rise, we use the R\&R-1999 grounding line. For the Larsen A embayment, we use the MOA-2004 grounding line. In Table 2, we partition between (1) the volume losses from grounded ice that completely disappeared (i.e. calved into icebergs) between November 2001 and November 2006 and (2) the net volume losses from the grounded ice that was still present in November 2006. The first category includes some areas that were grounded in the late 1990s but that may have become ungrounded before 2001, such as lower Crane Glacier (now fjord; section 3.3). In these regions, only the losses upstream of the ice flotation level will contribute to sea-level rise. The second category includes both upglacier areas where some elevation gains were observed and the main glacier troughs where significant losses occurred. We use the ice edge visible in the late 2006 SPOT5 imagery to discriminate ice losses into the two categories discussed above (Table 2). In addition, we define the limits of the drainage basins using the SPOT5 25 November 2006 DEM and, in some cases, visual inspection of the corresponding SPOT5 imagery.

The Drygalski Glacier front did not change much between November 2001 and November 2006, effectively standing at about the position of the MOA-2004 grounding line (Fig. 1g). Despite this, a surface lowering of $>30 \mathrm{~m}$ was observed during 2001-06 in the areas where DEM differences could be measured (Fig. 6), or more than $10 \mathrm{~m} \mathrm{a}^{-1}$ for the lower portion of the basin (Fig. 5a) during a period from 6 to $>14$ years after the early 1995 collapse of the Larsen A ice shelf (Rott and others, 1996) (Figs 3a and 5a). Over the whole basin (interpolated by hypsometry), Drygalski Glacier lost $\sim 15 \mathrm{~km}^{3}$ of ice through basin-average elevation losses of $\sim 3 \mathrm{~m} \mathrm{a}^{-1}$ over 2001-06 (Table 2). These findings are generally consistent with the observation of continuing fast flow and ice discharge in 2008 (Rott and others, 2011). Drygalski Glacier's long-term elevation and mass loss response suggests that similar losses from the Larsen B embayment glaciers will continue for many years after their adjacent ice-shelf collapse (e.g. as reported by Pritchard and others (2009) for other glaciers in the Antarctic Peninsula).

For grounded ice that calved, the average surface lowering was $\sim 80 \mathrm{~m}$ for lower Crane and Hektoria-Green 
Table 3. Published ice loss values for the Larsen A and B embayments $\left(\mathrm{Gt} \mathrm{a}^{-1}\right)$

\begin{tabular}{|c|c|c|c|c|}
\hline Source & Year & Larsen B & Larsen A (or by glacier name) & Larsen $\mathrm{A}+\mathrm{B}$ (or by glacier names) \\
\hline Rignot and others (2004) & 2003 & 27 & & \\
\hline Rignot (2006) & 2005 & & & $34 \pm 10$ (Drygalski to Leppard) \\
\hline \multirow[t]{2}{*}{ Rignot and others (2008) } & 1996 and 2000 & & & $3 \pm 1$ \\
\hline & 2006 & & & $31 \pm 9$ \\
\hline This paper ${ }^{\dagger}$ & $2001-06$ & $\begin{array}{c}8.4 \pm 1.7^{*} \text { without ice that } \\
\text { calved } \\
10.2 \pm 1.8^{+} \text {with ice that calved }\end{array}$ & $2.8 \pm 0.9^{*}$ (Drygalski only) & $\begin{array}{l}11.2 \pm 2.6 \text { without ice that } \\
\text { calved } \\
13 \pm 2.7 \text { with ice that calved } \\
\text { (Drygalski to Crane) }\end{array}$ \\
\hline
\end{tabular}

*Rott and others' (2011) Larsen A value not included here or in Larsen A+B total because it was presented only in their text as 'close to' the Larsen B value and includes smaller tributary glaciers flowing into Prince Gustav Channel (PGC).

${ }^{\dagger}$ Assumes ice loss applies to the whole November 2006 to November 2001 period. For Larsen B tributaries, only minor losses probably occurred during the first 6 months (between November 2001 and the ice-shelf break-up in March 2002).

${ }^{*} \mathrm{Gt} \mathrm{a}^{-1}$ rates are derived from the volume losses from Table 2 for each of the named glacier basins, multiplying by $900 \mathrm{~kg} \mathrm{~m}^{-3}$ and then dividing by 5 years.

Glaciers (Table 2). The average elevation changes on JorumPunchbowl and Evans Glaciers were close to $-40 \mathrm{~m}$. All these glaciers also experienced extensive ice-edge retreat and area loss (Fig. 1; Table 2). We note that the largest elevation losses $(-80,-120$ and $-160 \mathrm{~m}$ contours, Fig. 6) straddle the 2006 ice-edge position, with the very largest areas of elevation change being immediately adjacent to the seaward side of the 2006 ice edge (contours of $-120 \mathrm{~m}$ for Hektoria and Green Glaciers and $-160 \mathrm{~m}$ for Crane Glacier).

For grounded ice still present in late 2006, the basinaveraged thinning has the same magnitude for Hektoria, Green, Evans and Crane glaciers ( $30 \mathrm{~m}$; Table 2). The smaller Jorum-Punchbowl basin showed an overall more limited thinning of grounded ice $(\sim 9 \mathrm{~m})$ and this appears to be related to the basin being a composite of several smaller glaciers (Fig. 6). As shown by the elevation change contours, considerable grounded areas experienced locally higher elevation losses.

Our estimated annual volume loss from November 2006 to November 2001 is nearly $13 \mathrm{~km}^{3} \mathrm{a}^{-1}$ or $11.2 \mathrm{Gta}^{-1}$ (Table 2). This value may be as high as $13 \mathrm{Gta}^{-1}$ depending on the timing of grounding line migration for the major glaciers in the study area (see discussion above and two components of Table 2) as well as the net contribution of the areas with small changes (blue shading in Fig. 6). This corresponds to a eustatic contribution to sea-level rise of $>0.03 \mathrm{~mm} \mathrm{a}^{-1}, \sim 5-10 \%$ of the estimated overall contribution of the Antarctic ice sheet to sea-level rise during the same period (Allison and others, 2009; Cazenave and others, 2009). This total is also $\sim 30 \%$ of the GRACE-derived mass loss estimate of $\sim 40 \mathrm{Gta}^{-1}$ for the entire northern Antarctic Peninsula (Chen and others, 2009; Luthcke and others, 2009; Ivins and others, 2011). Our derived volumes and rates are substantially higher than the Larsen B assessment presented by Rott and others (2011) ( 4.3 Gta ${ }^{-1}$; Table 3) and are substantially smaller than the $27-34 \mathrm{Gta}^{-1}$ mass losses reported by Rignot and others $(2004,2008)$ and Rignot (2006) for slightly differing areas (Table 3).

We consider our mass-change estimate of $11.2 \mathrm{Gta}^{-1}$ to be a lower bound for several reasons. We restricted it to the main drainage basins (black outlines labeled by glacier in Fig. 6) where we could confidently detect a regional elevation loss of $>5 \mathrm{~m}$. Small basins in the Larsen B area near Crane fjord and the southern Larsen A embayment show apparent thinning of slightly more than $2 \mathrm{~m}$ between 2001 and 2006, but the data are noisy. A larger region $\left(\sim 4000 \mathrm{~km}^{2}\right)$ between Crane and Flask Glaciers, comprising Mapple, Melville, Pequod, Starbuck and Stubb glaciers (Fig. 6), experienced a $2.5 \mathrm{~m}$ thinning during the same period. However, these volume losses were not added to Table 3 because they remain below our detection threshold of $\pm 5 \mathrm{~m}$ and were thus uncertain in both space and time. Rather, we conclude there is basin-level stability for these glaciers (within our detection limit of $\pm 5 \mathrm{~m}$ ), and this conclusion is supported by examination of available inland ICESat track locations (Figs 1, 5 and 6). Additionally, because we could not confidently assess grounding line position changes (e.g. track 0129 cross sections over Jorum and Crane Glaciers; Figs 3e and 4a) accompanying the rapid elevation losses in the lowermost glacier areas during the study period, we assumed that all the ice that calved between the R\&R-1999 grounding line and the late 2006 SPOT5-derived ice edge did not contribute to the regional mass loss, even though that is probably not the case.

\section{SUMMARY AND CONCLUSIONS}

We investigated the elevation and mass-balance response of Larsen A and B ice shelf tributary glaciers during 2001-09. Our study used repeated MODIS images to track ice-extent losses in both embayments, and ASTER and SPOT5 DEMs plus ATM and ICESat laser altimetry to track elevation changes both spatially and temporally. Our study has provided insight into the continuing evolution of the glaciers and ice shelves in the Larsen A and B embayments in the years following the disintegrations of these ice shelves, and enables inferences to be drawn on further ice-shelf and glacier changes yet to come.

More than $300 \mathrm{~km}^{2}$ of ice area was lost from the Larsen A's margins between late 2001 and late 2009, primarily from the more exposed northern side of the Seal Nunataks ice shelf. For the Larsen B embayment, the ice-shelf area continued to diminish following its rapid collapse in 2002. Between late 2002 and 2009, total Larsen B ice shelf area losses exceeded $50 \%$ of the initial area lost $\left(1865 \mathrm{~km}^{2}\right.$ versus $3250 \mathrm{~km}^{2}$ in early 2002) due to large calving events from the 
SCAR Inlet ice shelf and overall ice-edge retreat. Ice-edge positions are now within fjords for most glaciers in the northern Larsen B embayment.

Elevation losses in the lower reaches of Hektoria, Green, Evans, Jorum and Crane glaciers, which flowed into Larsen B, exceeded $80 \mathrm{~m}$ over substantial portions of these glaciers and reached $>120 \mathrm{~m}$ and even $160 \mathrm{~m}$ in smaller areas during the study period. Changes to Crane Glacier's grounding line position may have occurred earlier than previously thought, apparently preceding ice-shelf collapse by at least 1 year. Other altimetry-data cross sections derived for this study revealed that glacier topography changed from concave- to convex-upward during the study period, indicating an inland migration of the grounding line for at least the lower Jorum and Evans Glaciers. This suggests that pre-break-up thinning of the Larsen B ice shelf, likely due to subglacial melting by warmer ocean water, may have played a significant role in preconditioning the ice shelf for rapid collapse and ice-edge retreat.

Center-line elevation differences have demonstrated the upstream migration of thinning of grounded glacial ice over the study period, as well as anomalously large elevation losses for one section of lower Crane Glacier (attributed to subglacial lake drainage in a deep submarine trough). A consistent pattern of broadening and upstream migration of a kinematic wave of elevation loss was observed for the Hektoria, Jorum and Crane glaciers. The limited elevation changes and limited ice front retreats detected on Melville, Pequod and Mapple glaciers appear related to the relatively shallow submarine troughs that were mapped in front of them. Observed changes on Flask and Leppard Glaciers were small, but appear synchronous, and showed a varying sign through the study period, suggesting the importance of the remnant SCAR Inlet ice shelf to their stability. Their scale, including tributaries like Fleece Glacier which flows into Leppard Glacier, appears generally similar to Crane Glacier and we believe that large elevation and volume losses will occur if the ice-shelf remnant is fully removed.

Combined mass losses (2001-06) for the major glaciers of the Larsen A/B systems as presented here total at least $11.2 \pm 2.6 \mathrm{Gt} \mathrm{a}^{-1}$ and could be as much as $13.0 \pm 2.7 \mathrm{Gt} \mathrm{a}^{-1}$ if ice lost to calving is included (Table 2). These altimetryderived values provide an independent check for other estimates of loss. Rott and others (2011) report a $4.3 \pm 1.6 \mathrm{Gta}^{-1}$ mass loss rate for the Larsen $\mathrm{B}$ glaciers in 2008. For the same region, our losses $\left(8.4 \pm 1.7 \mathrm{Gta}^{-1}\right.$; Table 3; Fig. 6) are distinctly different, especially because we excluded some small losses from three small glaciers south of Crane Glacier that they include (see Table 3 for specific areas). Rignot and others (2004, 2008) and Rignot (2006) report very large mass losses $\left(27-34 \mathrm{Gta}^{-1}\right)$ following iceshelf disintegration. Our net losses for similar areas and overlapping time periods are $41-33 \%$ of the values reported by Rignot and others. The large differences between these mass budget values and our altimetry-derived mass loss rates are likely due to errors (overestimation) in the assumed accumulation rate, flux-gate cross section, and grounding line position at the time of ice-shelf break-up. We note that the Rignot and others (2004, 2008) and Rignot (2006) studies may be unduly influenced by the very rapid mass losses in the period immediately following the Larsen B ice-shelf break-up.

The Drygalski Glacier surface is still lowering by several $\mathrm{m} \mathrm{a}^{-1}$ and losing $2.8 \pm 0.9 \mathrm{Gta}^{-1}$ of ice over the time period $>6$ to 14 years after ice-shelf disintegration. The continuing elevation changes and mass losses for Drygalski Glacier, even without further major ice-edge retreat during 2001-09, indicate that a long period of elevation and mass loss for Crane, Jorum, Hektoria, Green and Evans glaciers is still to come, lasting many years, possibly decades, into the future. Continued monitoring with airborne and satellite sensors will be needed to assess these expected changes in the years to come.

\section{ACKNOWLEDGEMENTS}

This work was supported by grants from NASA's Cryospheric Sciences Program. Data were provided by the ICESat Project and the ATM team. We also specifically thank the Chilean Centro de Estudios Científicos along with R. Thomas and W. Krabill and their team, for enabling the ATM data acquisitions prior to Operation IceBridge. E. Berthier acknowledges support from the French Space Agency (CNES) through the TOSCA and ISIS proposal No. 352. SPOT5 HRS data were provided at no cost by CNES through the SPIRIT International Polar Year project (Korona and others, 2009). ASTER data were provided at no cost by NASA/US Geological Survey through the Global Land Ice Measurements from Space (GLIMS) project (Raup and others, 2007). We thank P. Durand, M. Bernard (SPOT Image) and A. Orsoni (IGN Espace) for their early work on SPOT5 images of the Antarctic Peninsula. This study was also aided by J. Bohlander's searches for MODIS imagery, and V. Suchdeo who assembled the altimetry and imagery material into preliminary figures. F. Zgur and M. Rebesco facilitated our understanding of bathymetry data in the study area (principal investigator Eugene Domack, NSF-ANT03-38142). Finally, the paper was made substantially more coherent with patient editing by the scientific editors T.H. Jacka and H. Fricker, and reviewers B. Smith and D. Vaughan.

\section{REFERENCES}

Abdalati, W. and 16 others. 2010. The ICESat-2 laser altimetry mission. IEEE Proc., 98(5), 735-751.

Allison, I., R.B. Alley, H.A. Fricker, R.H. Thomas and R.C. Warner. 2009. Ice sheet mass balance and sea level. Antarct. Sci., 21(5), 413-426.

Berthier, E. and T. Toutin. 2008. SPOT5-HRS digital elevation models and the monitoring of glacier elevation changes in North-West Canada and South-East Alaska. Remote Sens. Environ., 112(5), 2443-2454.

Berthier, E., Y. Arnaud, D. Baratoux, C. Vincent and F. Rémy. 2004. Recent rapid thinning of the Mer de Glace glacier derived from satellite optical images. Geophys. Res. Lett., 31(17), L17401. (10.1029/2004GL020706.)

Berthier, E., E. Schiefer, G.K.C. Clarke, B. Menounos and F. Rémy. 2010. Contribution of Alaskan glaciers to sea-level rise derived from satellite imagery. Nature Geosci., 3(2), 92-95.

Brunt, K.M., H.A. Fricker, L. Padman, T.A. Scambos and S. O'Neel. 2010. Mapping the grounding zone of Ross Ice Shelf, Antarctica, using ICESat laser altimetry. Ann. Glaciol., 51(55), 71-79.

Cazenave, A. and 7 others. 2009. Sea level budget over 20032008: a reevaluation from GRACE space gravimetry, satellite altimetry and Argo. Global Planet. Change, 65(1-2), 83-88.

Chen, J.L., C.R. Wilson, D. Blankenship and B.D. Tapley. 2009. Accelerated Antarctic ice loss from satellite gravity measurements. Nature Geosci., 2(12), 859-862.

Cook, A.J. and D.G. Vaughan. 2010. Overview of areal changes of the ice shelves on the Antarctic Peninsula over the past 50 years. Cryosphere, 4(1), 77-98. 
Cook, A.J., A.J. Fox, D.G. Vaughan and J.G. Ferrigno. 2005. Retreating glacier fronts on the Antarctic Peninsula over the past half-century. Science, 308(5721), 541-544.

De Angelis, H. and P. Skvarca. 2003. Glacier surge after ice shelf collapse. Science, 299(5612), 1560-1562.

Fahnestock, M.A., W. Abdalati and C.A. Shuman. 2002. Long melt seasons on ice shelves of the Antarctic Peninsula: an analysis using satellite-based microwave emission measurements. Ann. Glaciol., 34, 127-133.

Ferrigno, J.G. and 7 others. 2006. Coastal-change and glaciological map of the Trinity Peninsula Area and South Shetland Islands, Antarctica: 1843-2001. Reston, VA, US Geological Survey. (Geologic Investigations Series Map 1-2600-A.)

Ferrigno, J.G. and 8 others. 2008. Coastal-change and glaciological map of the Larsen Ice Shelf area, Antarctica, 1940-2005. Reston, VA, US Geological Survey. (Geologic Investigations Series Map I-2600-B.)

Fricker, H.A., T. Scambos, R. Bindschadler and L. Padman. 2007. An active subglacial water system in West Antarctica mapped from space. Science, 315(5818), 1544-1548.

Fujisada, H., G.B. Bailey, G.G. Kelly, S. Hara and M.J. Abrams. 2005. ASTER DEM performance. IEEE Trans. Geosci. Remote Sens., 43(12), 2707-2714

Glasser, N.F. and T.A. Scambos. 2008. A structural glaciological analysis of the 2002 Larsen B ice-shelf collapse. J. Glaciol., 54(184), 3-16.

Hughes, T. 1975. The West Antarctic ice sheet: instability, disintegration, and initiation of ice ages. Rev. Geophys. Space Phys., 13(4), 502-526.

Hulbe, C.L., T.A. Scambos, T. Youngberg and A.K. Lamb. 2008. Patterns of glacier response to disintegration of the Larsen B ice shelf, Antarctic Peninsula. Global Planet. Change, 63(1), $1-8$.

Ivins, E.R., M.M. Watkins, D.-N. Yuan, R. Dietrich, G. Casassa and A. Rülke. 2011. On-land ice loss and glacial isostatic adjustment at the Drake Passage: 2003-2009. J. Geophys. Res., 116(B2), B02403. (10.1029/2010JB007607.)

King, J.C. and J.C. Comiso. 2003. The spatial coherence of interannual temperature variations in the Antarctic Peninsula. Geophys. Res. Lett., 30(2), 1040. (10.1029/2002GL015580.)

Korona, J., E. Berthier, M. Bernard, F. Rémy and E. Thouvenot. 2009. SPIRIT. SPOT 5 stereoscopic survey of Polar Ice: reference images and topographies during the fourth International Polar Year (2007-2009). ISPRS J. Photogramm. Rem. Sens, 64(2), 204-212.

Krabill, W.B. and 8 others. 2002. Aircraft laser altimetry measurements of changes of the Greenland ice sheet: technique and accuracy assessment. J. Geodyn., 34(3-4), 357-376.

Luthcke, S.B. and 6 others. 2009. Recent changes in the Earth's land ice from GRACE: methods, signals and error. [Abstr. H13G-02.] Eos, 90(52), Fall Meet. Suppl.

Marshall, G.J., A. Orr and N.P.M. van Lipzig. 2006. The impact of a changing Southern Hemisphere Annular Mode on Antarctic Peninsula summer temperatures. J. Climate, 19(20), 5388-5404.

Mercer, J.H. 1978. West Antarctic ice sheet and $\mathrm{CO}_{2}$ greenhouse effect: a threat of disaster. Nature, 271(5643), 321-325.

Mueller, R.D. and 6 others. 2006. Ocean/ice-shelf interactions around collapsing Antarctic Peninsula Ice Shelves. [Abstr. C41C0346.] Eos, 87(52).

Pritchard, H.D. and D.G. Vaughan. 2007. Widespread acceleration of tidewater glaciers on the Antarctic Peninsula. J. Geophys. Res., 112(F3), F03S29. (10.1029/2006JF000597.)

Pritchard, H.D., R.J. Arthern, D.G. Vaughan and L.A. Edwards. 2009. Extensive dynamic thinning on the margins of the Greenland and Antarctic ice sheets. Nature, 461(7266), 971-975.

Rack, W. and H. Rott. 2004. Pattern of retreat and disintegration of the Larsen B ice shelf, Antarctic Peninsula. Ann. Glaciol., 39, 505-510.
Raup, B. and 11 others. 2007. Remote sensing and GIS technology in the Global Land Ice Measurements from Space (GLIMS) Project. Comput. Geosci., 33(1), 104-125.

Rignot, E. 2006. Changes in ice dynamics and mass balance of the Antarctic ice sheet. Philos. Trans. R. Soc. London, Ser. A, 364(1844), 1637-1655.

Rignot, E., G. Casassa, P. Gogineni, W. Krabill, A. Rivera and R. Thomas. 2004. Accelerated ice discharge from the Antarctic Peninsula following the collapse of Larsen B ice shelf. Geophys. Res. Lett., 31(18), L18401. (10.1029/2004GL020697.)

Rignot, E. and 6 others. 2008. Recent Antarctic ice mass loss from radar interferometry and regional climate modelling. Nature Geosci., 1(2), 106-110.

Robin, G.de Q. and R.J. Adie. 1964. The ice cover. In Priestley, R., R.J. Adie and G.de Q. Robin, eds. Antarctic research: a review of British scientific achievement in Antarctica. London, Butterworths, 100-117.

Rott, H., P. Skvarca and T. Nagler. 1996. Rapid collapse of northern Larsen Ice Shelf, Antarctica. Science, 271(5250), 788-792.

Rott, H., W. Rack, P. Skvarca and H. De Angelis. 2002. Northern Larsen Ice Shelf, Antarctica: further retreat after collapse. Ann. Glaciol., 34, 277-282.

Rott, H., F. Müller, T. Nagler and D. Floricioiu. 2011. The imbalance of glaciers after disintegration of Larsen-B ice shelf, Antarctic Peninsula. Cryosphere, 5(1), 125-134.

Scambos, T.A., C. Hulbe, M. Fahnestock and J. Bohlander. 2000. The link between climate warming and break-up of ice shelves in the Antarctic Peninsula. J. Glaciol., 46(154), 516-530.

Scambos, T., C. Hulbe and M. Fahnestock. 2003. Climate-induced ice shelf disintegration in the Antarctic Peninsula. In Domack, E.W., A. Burnett, A. Leventer, P. Conley, M. Kirby and R. Bindschadler, eds. Antarctic Peninsula climate variability: a historical and paleoenvironmental perspective. Washington, DC, American Geophysical Union, 79-92. (Antarctic Research Series 79.

Scambos, T.A., J.A. Bohlander, C.A. Shuman and P. Skvarca. 2004. Glacier acceleration and thinning after ice shelf collapse in the Larsen B embayment, Antarctica. Geophys. Res. Lett., 31(18), L18402. (10.1029/2004GL020670.)

Scambos, T.A., T.M. Haran, M.A. Fahnestock, T.H. Painter and J. Bohlander. 2007. MODIS-based Mosaic of Antarctica (MOA) datasets: continent-wide surface morphology and snow grain size. Remote Sens. Environ., 111(2-3), 242-257.

Scambos, T.A., E. Berthier and C.A. Shuman. 2011. The triggering of subglacial lake drainage during rapid glacier drawdown: Crane Glacier, Antarctic Peninsula. Ann. Glaciol., 52(59), 74-82.

Schutz, B.E., H.J. Zwally, C.A. Shuman, D. Hancock and J.P. DiMarzio. 2005. Overview of the ICESat Mission. Geophys. Res. Lett., 32(21), L21S01. (10.1029/2005GL024009.)

Shepherd, A., D. Wingham, T. Payne and P. Skvarca. 2003. Larsen ice shelf has progressively thinned. Science, 302(5646), 856-859.

Shuman, C.A. and 6 others. 2006. ICESat Antarctic elevation data: preliminary precision and accuracy assessment. Geophys. Res. Lett., 33(7), L07501. (10.1029/2005GL025227.)

Skvarca, P., W. Rack, H. Rott and T. Donángelo. 1999. Climatic trend and the retreat and disintegration of ice shelves on the Antarctic Peninsula: an overview. Polar Res., 18(2), 151-157.

Smith, B.E., C.R. Bentley and C.F. Raymond. 2005. Recent elevation changes on the ice streams and ridges of the Ross Embayment from ICESat crossovers. Geophys. Res. Lett., 32(21), L21S09. (10.1029/2005GL024365.)

Smith, B.E., H.A. Fricker, I.R. Joughin and S. Tulaczyk. 2009. An inventory of active subglacial lakes in Antarctica detected by ICESat (2003-2008). J. Glaciol., 55(192), 573-595.

Sun, X., J.B. Abshire and D. Yi. 2004. Geoscience laser altimeter system: characteristics and performance of the altimeter receiver. [Abstr. C32A-0432.] Eos, 84(46), Fall Meet.Suppl.

Thomas, R. and 17 others. 2004. Accelerated sea-level rise from West Antarctica. Science, 306(5694), 255-258. 
Thomas, R., E. Frederick, W. Krabill, S. Manizade, C. Martin and A. Mason. 2005. Elevation changes on the Greenland ice sheet from comparison of aircraft and ICESat laser-altimeter data. Ann. Glaciol., 42, 77-82.

Toutin, T. 2002. Three-dimensional topographic mapping with ASTER stereo data in rugged topography. IEEE Trans. Geosci. Remote Sens., 40(10), 2241-2247.

Van den Broeke, M. 2005. Strong surface melting preceded collapse of Antarctic Peninsula ice shelf. Geophys. Res. Lett., 32(12), L12815. (10.1029/2005GL023247.)

Vaughan, D.G. and C.S.M. Doake. 1996. Recent atmospheric warming and retreat of ice shelves on the Antarctic Peninsula. Nature, 379(6563), 328-331.
Vaughan, D.G., G.J. Marshall, W.M. Connolley, J.C. King and R. Mulvaney. 2001. Climate change: devil in the detail. Science, 293(5536), 1777-1779.

Vaughan, D.G. and 8 others. 2003. Recent rapid regional climate warming on the Antarctic Peninsula. Climatic Change, 60(3), 243-274.

Vieli, A., M. Funk and H. Blatter. 2001. Flow dynamics of tidewater glaciers: a numerical modelling approach. J. Glaciol., 47(159), 595-606.

Vieli, A., A.J. Payne, A. Shepherd and Z. Du. 2007. Causes of precollapse changes of the Larsen B ice shelf: numerical modelling and assimilation of satellite observations. Earth Planet. Sci. Lett., 259(3-4), 297-306.

MS received 28 September 2010 and accepted in revised form 9 April 2011 